\title{
Artificial Neural Network Methodology In Fraud Risk Prediction On Financial Statements; An Emprical Study In Banking Sector
}

\author{
Mustafa UĞURLU \\ Gaziantep University, \\ Social Sciences Vocational School, \\ Department of Accounting and Tax, \\ Gaziantep, Turkey \\ ugurlu@gantep.edu.tr
}

\author{
Şerafettin SEVIM \\ Dumlupınar University, \\ Faculty of Economics and Administrative \\ Sciences, Department of Business, \\ Kütahya, Turkey \\ sevim@dpu.edu.tr
}

\begin{abstract}
Credit risk is among the foremost risk factors that banks may encounter. Banking function is rendering credits. In rendering commercial credits based on fraudulent financial statements, credit risk can occur if banks cannot ensure the repayments of credits completely or partially. This case lead to an important problem for banks. The accuracy and reliability of information provided by financial statements are of crucial importance in credit risk management. In this context, main purpose of this study is to make it possible to predict fraud risk in financial statements. By doing so, it is possible prevent credit risk that may emerge in banks. In this study, to predict and determine fraud risk in financial statements, artificial neural network (ANN) methodology is utilized. This research includes commercial and corporate customers of banks. Financial data of 289 firms, belonging to the year of 2007, (97 firms were assumed to have fraudulent financial statements and 192 firms were in control group) was analyzed, and an ANN model is proposal. The proposal model that was developed is highly successful in predicting fraud risk in financial statements with an accuracy ratio of $90 \%$.
\end{abstract}

Keywords: Financial Information, Financial Statement Fraud, Prediction of Financial Statement Fraud, Artificial Neural Network

\section{Introduction}

Fraud is a deception willfully practiced in order to secure unfair or illegal gain (Jackson, 1999, p.163). Two types of fraud have been reported in the literature. The former is the faulty allocation of assets and the latter is financial statement fraud. (Apostolou et al., 2001, p.49). The faulty allocation of assets involves crimes such as obvious theft, embezzlement, unjust loading to expense items, abuse of firm assets etc.

On the other hand, financial statement fraud is a kind of crime, which does not include theft in literal terms, but involves the deliberate distortion of financial statements. This type of fraud can be exemplified with sales, pretended sales, the 
presentation of the subsequent year's profit as belonging to the current year, the inappropriate activation of expenditures, or the presentation of current year's expenditures as belonging to the subsequent year (Braiotta, 2004, pp.112-115).

The 1999 COSO (Committee of Sponsoring Organizations) report revealed that $90 \%$ of detected fraud is based on the manipulation of financial information declared to the public, and 10\% of them occur as a result of abuse of assets (Reazee, 2005, p. 282).

In the past, a great many financial scandals came up especially concerning fraud conducted by the white-collared. Among these are well-known companies such as Enron, WorldCom, Tyco, Village, Peregrine Systems, Lucent, Martha Stewart, Imclone, Xerox, Parmalat, Barings Bank, BCCI, Rite Aid, Cendant, Sunbeam, Waste Management, Global Crossing, Adelphia Communications. It has been stated that Enron financial loss its creditors, investors, employees and pensioners by 70 billion dollars through financial statement fraud. Similarly the loss that was caused by financial statement fraud in WorldCom has been reported to be the biggest loss in the history of the US. It has also been stated that the financial loss which Enron, WorldCom, Qwest, Tyco and Global Crossing caused in market capitalization by resorting to financial statement fraud was approximately 460 billion dollars (Rezaee, 2005, p. 278).

The total cost of financial statement fraud for market participants (creditors, investors, employees, pensioners etc.) was over 500 billion dollars in the past (Ugrin ve Odom, 2010, p. 440). Specifically, participants of money and capital markets place great importance on effective corporate governance which form trust in terms of the quality, accuracy and transparency of financial information. However the scandalous events in the past (Enron, WorldCom etc.) created distrust for audited and published financial statements on the side of market participants and led to suspicion for even externally audited financial statements. Thus, financial statement fraud has come to the fore following these events. And recently the business world, accounting experts, academics and regulators have stated serious warnings about financial statement fraud.

The definition of financial statement fraud has varied among academics, relevant researchers and auditors. In this context, there is no agreed upon definition of the "financial statement fraud" concept. The most important reason for this is that, until recent years, this term is not accurately identified and stated. Accounting experts have preferred the term "delivered mistakes and irregularities".

Financial statement fraud is generally conducted by the management or employees authorized and/or charged by the management. Therefore, Elliott and Willingham (1980) regard financial statement fraud as management fraud. Elliott and Willingham (1980) define financial statement fraud as to damage investors and creditors using misleading financial statements done by the management (Elliott and Willingham, 1980, p. 4).

Financial statement fraud is done with the purpose of manipulating an organization's accounts. For example, it presents itself as manipulation of income, activation of expenditures, hiding debts that cannot be recovered or doing selective practices in accounting principles in order to give a false impression of the financial position or performance of an entity for a given period (KPMG, 2004).

Management fraud and financial statement fraud are frequently used interchangeably. Despite differences between the general definition of fraud and the 
definition financial statement fraud, the common point is that there is a tendency of "deliberateness and damage to other parties" in both. Investors, creditors and auditors are among loss sufferers and these people suffer not only financial loss (position loss, fines etc.) but also prestige loss (Rezaee, 2002, p. 68).

Rezaee (2005) defines financial statement fraud as deliberate attempts by companies to cheat or misguide financial statement users (especially creditors and investors) by arranging manipulated financial statements and releasing them to the public.

Financial statement fraud can be more comprehensive and planned when conducted by some senior executives or auditors who are successful and knowledgeable in this area which possesses the characteristics of deliberateness and fraudulency.

Wells (2004), by analyzing the Enron scandal, which occurred in the USA, categorized those who resort to financial statement fraud as follows:

- Chief Executive Officers(CEO),

- Middle and low degree workers (Especially by bribery),

- Organized Offender (Especially by line your own pockets).

While there are various factors that cause the manipulation of financial statements, those who manipulate financial statements can do this using a lot of methods (Madura, 2004, p. 176).

Reazee(2005) reports that $80 \%$ of financial statement fraud and financial statement manipulation is done by overstating assets and profits, and $20 \%$ of them by understating debts and expenditures. Therefore, Reazee (2005) emphasizes the fact that "earnings management" and "aggressive accounting practices" are important methods used in financial statement fraud (Reazee, 2005, p. 282).

Wells (2004) states that the methods used in financial statement fraud vary in accordance with the size of fraud practices and that there are basically three methods that lead to financial statement fraud:

a- Manipulating the Accounting System: In this method those who do financial statement fraud use the accounting system as a developmental tool in line with their demands. For instance, financial information users are cheated by enabling the overstatement of earnings and assets and understatement of debts and expenditures through creative or deceptive accounting practices such as making more or less provision then necessary for doubtful receivables, making too low or too high provisions, showing unrealized sales as realized sales, making fictive sale entries, understating or overstating inventories, not recording borrowings etc.

b- Deformation of the Accounting System: In this method, those who conduct financial statement fraud manipulate financial information presented with reports by adding false and imaginary information to the results reported in the accounting system.

c- Using Means other than the Accounting System: In this method, those who conduct financial statement fraud cheat financial information users by falsifying documents containing accurate financial information supported with the reports of the accounting system or replacing current reports with falsified ones and profit from this. 
McKee (2005) identifies two basic approaches explaining the purpose of financial statement fraud. The former of these approaches points to the fact that manager's resort to financial statement fraud so as to increase their personal power, status and prosperity. In this approach, managers do financial statement fraud in order to (1) get high incentive bonus, (2) to maintain their efficiency and power in the firm and (3) to get promotion (McKee, 2005, p. 23).

The second approach indicates that managers do financial statement fraud to overstate the performance of the firm. In this approach, the basic motives that lead to financial statement fraud are the firms' interests rather than personal interests. In this framework, manager's resort to financial statement fraud in order to (1) maximize the firm value, (2) minimize the bankruptcy risk, (3) prove appropriateness for the criteria and conditions in credit contracts and (4) avoid accusations in the auditing done by regulators on the firm (McKee, 2005, p. 23).

Financial statement fraud both misguides financial information users regarding a firm's real financial situation and operating results and leads to the false and ineffective use of resources by causing loss of investors related to the firm, shareholders and creditors.

In this context, while the most significant result of financial statement fraud has been stated to be the false and ineffective use of economic resources. Kucuksozen and Kucukkocaoglu (2004) list the other results caused by financial statement fraud as follows (Kucuksozen and Kucukkocaoglu, 2004, p. 10):

- The decrease in the price of common stocks and the value of firms,

- The increase in the cost of loan,

- Damage of a lot of creditors and investors,

- Distrust of creditors and investors to companies,

- The decrease in the number of analysts pursuing firms which resort to financial statement fraud,

- The decrease in accuracy of predictions of analysts regarding firms,

- Corruption roles of monetary and capital markets in the allocation of resources to effective areas,

- Lay-off managers and employees who manipulate financial statement and

- The withdrawal of external auditing organizations from external auditing.

\section{Prior Research}

Past financial statement fraud cases and loss resulting from these cases have brought about the necessity for early warning systems that enable the detection of financial statement fraud in advance. A lot of models have been developed for the detection of fraudulent financial statements as a result of numerous empirical studies (Nigai et al., 2011; Ravisankar et al., 2011; Humpherys et al., 2011; Zhou and Kapoor, 2011; Perols and Lougee, 2010; Ata and Seyrek, 2009; Kirkos, 2007; Kuçukkocaoglu et al., 2007; Kuçuksozen, 2004; Spathis et al., 2004; Spathis, 2002; Beneish, 1999; Beneish, 1997) and the relative success of these models have been discussed.

Beneish (1997) presented a model that will reveal companies with fraudulent financial statements through analyses on companies with extraordinary financial performance. In the study, the author analyzed the financial statements of 64 listed companies whose manipulation of financial statements between the years 1987-1993 
through violating accounting standards was detected with the auditing of capital market boards.

Beneish (1997) compared the financial ratios of companies which committed financial statement fraud with the financial ratios of companies which did not violate generally accepted accounting standards. Beneish (1997), in order to detect financial statement fraud, used the variables "Days' sales in receivables index (DSRI)", "Gross profit margin index (GMI)", "Assets quality index (AQI)", "Depreciation index (DI)", "Sales growth index (SGI)", "Sale, general and administrative expenses index (SGAI)" and "Total accruals to total assets (TATA)". In this model, to measure the capacity of companies to resort to financial statement fraud a secondary data set containing the variables "Capital structure", "Prior market performance", "Ownership structure", "Time listed", "Sales growth", "Prior positive accruals decisions" and "Independent auditors" was used.

Beneish (1997) summarizes the characteristic properties of companies who conduct financial statement fraud as generally newly founded, with low common stock performance, growing with debt-weighted capital structure, with gradually decreasing account receivable and inventory turnover ratios, and decreasing asset quality and gross profit margin.

Beneish (1999), unlike the 1997 study, used a bigger sample and tested the model on 74 firms who were detected to have conducted financial statement fraud. 2,332 firms who were assumed not to have resorted the financial statement fraud were included in the analyses as the control group.

While in the 1997 study, the control group was sampled among companies with high unexpected accruals; in the 1999 model they were chosen from companies who were assumed not to have conducted financial statement fraud who operate in the same industry as the companies who were assumed to have conducted financial statement fraud.

Beneish (1999) used the same model as in their 1997 study. However, Beneish (1999), altered the independent variables used in 1997 study and subjected the financial data stated below obtained from companies who resorted to financial statement fraud and control group to probit analysis:

- Days' sales in receivables index (DSRI),

- Gross profit margin index (GMI),

- Assets quality index (AQI),

- Depreciation index (DI),

- Sale, general and administrative expenses index (SGAI),

- Total accruals to total assets (TATA),

- Sales growth index (SGI),

- Leverage index (LVGI)

According to findings of the analyses conducted in the framework of Beneish (1999), it was found out that an extraordinary increase in accounts receivable, a decrease in gross profit margin, a decrease in asset quality, increase in sales and accruals may be indicative of whether a company has resorted to financial statement fraud. 
In the study conducted by Beneish (1999), the representativeness of the model was stated to be between $31-37 \%$, whereas its prediction power was assumed to be between $38-56 \%$.

On the other hand Beneish (1999) predicted two errors in the model, which are summarized as follows:

- Error 1: The estimation of companies who resort to financial statement fraud as companies who do not.

-Error 2: The estimation of companies who do not resort to financial statement fraud as companies who do.

Spathis (2002), in the detection of financial statement fraud, founded a logit model by using logistic regression analysis. In this study, 76 companies who are quoted in Athens Stock Exchange and operate in real sector were taken as the sample. Banks, insurance companies and other companies who operate in the financial sector were excluded.

Spathis (2002) used 4 parameters in the detection of companies with fraudulent financial statements:

- An opinion in external auditing reports regarding serious doubts of accounting fraud

- A detection of serious findings by relevant authorities of tax evasion by the company

- The placement of company common stocks in watch list companies market by the Capital Markets Board (CMB) or cancelation of company common stocks,

- The detection by court of violation of laws by the company.

In this framework, Spathis (2002) sampled 38 companies as firms who conducted financial statement fraud and included them in the model. Besides these companies who were assumed to have conducted financial statement fraud 38 other companies listed in Athens Stock Exchange who were assumed not to have conducted it were taken as the control group. In this study, 17 variables were chosen as potential risk indicators from the studies of Green and Choi (1997), Hoffman (1997), Hollman and Patton (1997), Zimbelman (1997), Beneish (1997), Beasley (1996), Bologna et al. (1996), Arens and Loebbecke (1994), Bell et al. (1993), Schilit (1993), Davia et al. (1992), Stice (1991), Loebbecke et al. (1989), Palmrose (1987) and Albrecht and Romney (1986) in order to identify companies who conducted financial statement fraud. However, Spathis (2002) reduced the number of variables to 10 by eliminating financial ratios with high correlation among these variables. In this framework, Spathis (2002) identified the variables to be used in the detection of companies resorting to financial statement fraud as follows: (1) Debt/Equity (D/E), (2) Total Sales/Total Assets (Sales/TA), (3) Net Profit/Sales (NP/Sales), (4) Receivables/Sales (Rec/Sales), (5) Net Profit/Total Assets (NP/TA), (6) Working Capital/Total Assets (WC/TA), (7) Gross Profit/Total Assets (GP/TA), (8) Inventory/Total Assets (INV/TA), (9) Total Debt/Total Assets (TD/TA), (10) Altman Z-score. 
Spathis (2002) analyzed the 2000 data of the companies resorting to fraud and control companies to be able to detect financial statement fraud and formed the following model:

FFS $=$ b0 $+b 1(D / E)+b 2($ Sales/TA $)+b 3(N P /$ Sales $)+b 4($ Rec/Sales $)+b 5(N P / T A)$ $+\mathrm{b} 6(\mathrm{WC} / \mathrm{TA})+\mathrm{b} 7(\mathrm{GP} / \mathrm{TA})+\mathrm{b} 8(\mathrm{INV} / \mathrm{Sales})+\mathrm{b} 9(\mathrm{TD} / \mathrm{TA})+\mathrm{b} 10$ (Altman Z-score)

Spathis (2002), as a result of the analyses, found out statistically significant relationship between financial statement fraud and the following three variables $(p<.01)$ : (1) Inventory/Total Assets (INV/TA), (2) Total Debt/Total Assets (TD/TA), (3) Altman Z-score.

Kirkos et al. (2007) used the artificial neural network technology in the detection of financial statement fraud and used the sample and data set utilized by Spathis (2002). In this study, after the first learning took place and one of the alternative designs was tested, a typology involving five hidden nodes for each hidden layer was chosen. The chosen network was structured by the repeated testing of the training set and its application to the whole sample. In this research, the success of the structured model in accurate classification of companies who were assumed to have fraudulent financial statements was measured to be $100 \%$. Nevertheless, the relative power of the values which were going to be used as input in one neuron could not be estimated, because the software used by Kirkos et al. (1997) could not calculated the synaptic weight of the connection between neurons.

Ravisankar et al. (2011) comparatively analyzed the predictive success in the detection of financial statement fraud of data mining techniques used in the detection of financial statement fraud risk. Ravisankar et al. (2011) analyzed the financial statements of 202 industrial companies listed in the Chinese Stock Exchange. In this study, 101 companies who received adverse or qualified opinions in the audits done by external auditors were chosen as firms with fraudulent financial statements, whereas the other 101 companies who were assumed not to have conducted financial statement fraud were specified as the control group. Ravisankar et al. (2011) initially determined 38 financial ratios in order to identify companies with fraudulent financial statement and subjected these 38 financial ratios to T-tests by extracting the data from the financial statements of the 202 companies. According to the results of the T-tests, 18 financial ratios presented statistically significance differences in the detection of financial statement fraud and these variables were taken as independent variables and analyzed for the estimation of the fraud risk in financial statements: (1) Net Profit, (2) Gross Profit, (3) Sales, (4) Sales/Total Assets, (5) Gross Profit/Total Assets, (6) Net Profit/Total Assets, (7) Inventory/Total Assets, (8) Inventory/Short Term Debt, (9) Net Profit/Sales, (10) Sales/Fixed Assets, (11) Operating Profit/Closing Year Operating Profit, (12) Sales/Closing Year Sales, (13) Fixed Assets/Total Assets, (14) Current Assets/Short Term Debt, (15) Equity/Total Debt, (16) Long Term Debt/Equity, (17) Cash Ratio, (18) Inventory/Sales.

Ravisankar et al. (2011), calculating these 18 variables for the 202 companies, comparatively analyzed the predictive success in the detection of financial statement fraud risk of the neural networks, genetic algorithms and logistic regression models which used these variables. According to the result of analyses the most successful model was the ANN model with $96 \%$ accurate classification, followed by genetic algorithms with $93 \%$ accurate classification. 
Ngai et al. (2011) demonstrated that models with multiple variables such as ANN, logistic regression, bayes and decision tree are commonly used in the detection of financial statement fraud, having analyzed studies in the literature in terms of their chronology, methodology, content and objectives.

In Turkey, Kucukkocaoglu et al. (2007), attempted to distinguish companies who did and did not resorted to financial statement fraud using artificial neural network model. In the study, the variables used in the studies of Beneish (1997-1999) were adopted and the power of the model was tested using ANN model. As a result of this study the predictive power of the model in the detection of financial statement fraud was determined to be $86.17 \%$ and the probability of inaccurate classification to be $13.82 \%$.

Moreover, it was stated in the study that the ANN model could be used to predict the future states of the companies entering the model, when the variables that can be used in the detection of financial statement fraud are known.

\section{Research Methodology}

One of the significant problems creditor companies face is how to prevent the use of credits based on fraudulent financial statements that cause bad loans. This study was conducted towards the solution of this problem. Therefore, the main purpose of the study is to prevent credit use based on fraudulent financial statement by developing a model that can predict fraud risk in financial statements and prevent the credit risk for banks.

One of the primary and maybe the most important issues that banks deal with due to their activities is the prevention of bad loans. According to the date provided by the Banks Association of Turkey, the provision for non-performing loans of the banks operating in Turkey for the year 2013 is $\$ 13.9$ billion and corporate/commercial loans had the biggest increase among non-performing loans in 2013 with a rise of $\$ 1.03$ billion (BDDK, 2013, p. 29).

Especially countries with a low propensity to save force the effective and efficient use of current savings by the real sector through the banks. This model study which forecasts and values the fraud risk in financial statements during the assessment of commercial loan demands is of great significance in terms of the effective and efficient use of current saving through banks, since it prevents credit use based on fraudulent financial statements.

One of the significant problems of banks is bad loans formed as a result of credit use based on fraudulent financial statement. Therefore, this study bears great importance in terms of presenting a very important projection for the solution of this problem.

A number of studies on companies which are listed stock exchange are present in the literature regarding the detection of fraudulent financial statements. When relevant studies (Nigai et al., 2011; Ravisankar et al., 2011; Humpherys et al., 2011; Zhou and Kapoor, 2011; Perols and Lougee, 2010; Ata and Seyrek, 2009; Kirkos, 2007; Kuçukkocaoglu et al., 2007; Kucuksozen and Kucukkocaoglu, 2004; Spathis, 2004; Spathis, 2002; Beneish, 1999; Beneish, 1997) in the literature are examined, it has been observed that almost all the studies involve models developed for the prevention of manipulations towards common stock investments. 
However, this study is significantly different from the literature in that the sample was chosen from not listed stock exchange commercial and corporate companies which are clients to banks, that the study targets the banking sector, and that the model developed in the framework of the study aims to detect manipulations conducted against creditor institutions.

The current study that was conducted for the identification of fraud risk in financial statements also has some limitations. First, the financial data of not listed stock exchange manufacturing firms that used credit from a bank have established while generating this model. Therefore, this model cannot produce accurate results in terms of fraud risk detection in financial statements of the listed stock exchange companies and sectors except manufacturing industry.

In this study, the sample is formed of corporate and commercial firms whose sales exceed 10 million TL and who are clients to banks. Therefore, as regards scale, the study may not present successful results for micro and small size companies whose sales are below 10 million TL.

Another limitation of the study is the assumption that no inaccurate credit scoring has been carried out based on staff error, inadequate information or other reasons in the internal credit scoring realized by expert staff. Therefore, the presence of companies with an inaccurate credit scoring caused by staff in the sample may lead to the production of inaccurate results by the model developed in the framework of the study.

In the framework of the study "companies whose internal credit scoring is rather credible but whose credit loans have been transferred to bad loan account because they could not fulfill their financial obligations in time, thereby being exposed to legal proceedings due to their credit loans" were assumed to be companies with financial statement fraud. However, no analysis or assessment could be conducted about whether the companies classified into the manipulator and control groups actually did or did not resorted to financial statement fraud. Therefore, in the context of the present study there may be some companies whose financial statements are accurate but who could not fulfill their credit obligations because of bank policy, problems cause of sectorial and economic conjuncture, new legal regulations towards the operating sector of the company etc. among the companies who were assumed to have fraudulent financial statements. On the contrary, there may also be some companies who do not experience any problems paying their loans back based on some variables independent of financial statements (that stockholders of the company have liquid assets which are not reflected in their financial data, that the manipulation is done for tax-related purposes etc.), although actually they resorted to financial statement fraud. Even though the companies in this context have been considered as Type- 1 and Type- 2 errors in the framework of the model the success of the model will be adversely affected by the excessively white size of the sample.

Commercial and corporate clients who used commercial credits from banks make up the scope of the study. In this context, ANN methodology has been utilized for the purpose of detecting whether the aforementioned companies have conducted financial information manipulation. ANN is an information-processing system involving some performance futures similar to an inspired by biological neural network (Fausett, 1994, p. 3). 
ANN is an information-processing methodology inspired by the information processing technology of the human brain.

Figure 1: The structure of biological neurons

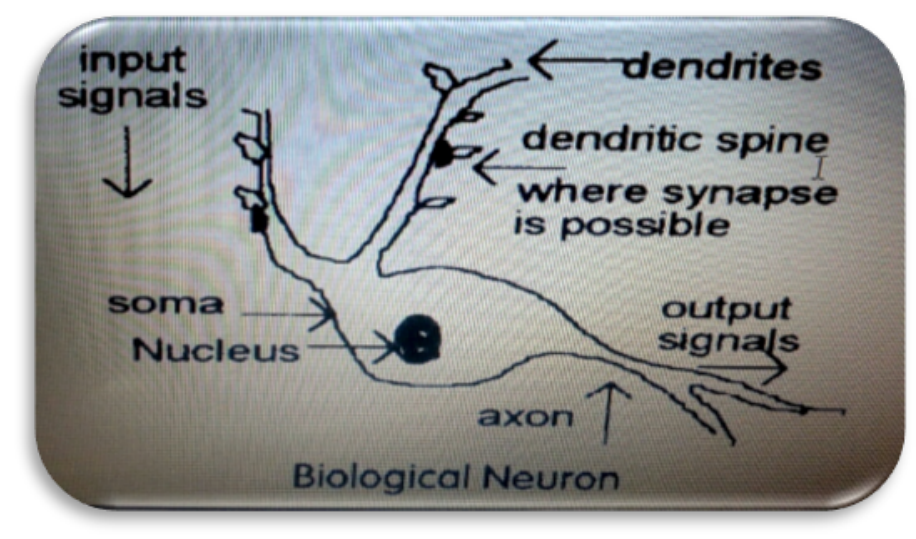

Figure 1 shows structure of biological neurons. Four important parts called axon, dendrite, synapses and soma connect two neurons together (Raol and Mankame, 1996, p. 48)

Axon: It is the projection that senses the cell output. A single cell has one axon projection and a number of synaptic connections extended from this projection.

$>$ Dendrites: They are the projection of a neuron that resemble tree roots and provide input to the cell.

$>$ Synapse: They are specialized connection points of axons which end on other neurons or end on their dendrites. These connection points enable the transfer of the electrical message in the axon to the other cells.

$>$ Soma: The body of a neuron is called the soma. The soma involves the cell nucleus and performs functions to enable the survival of the cell.

ANN is likened to a simple biological neural system in its operation. Structured neural cells involve neurons and these neurons form the network by connecting to each other in various ways. These networks are capable of storing in the memory and revealing the relationship between pieces of data (Rud, 2001, p. 16).

Learning in biological systems occurs with the adjustment of synaptic links between neurons that is; human beings enter the process of learning by experience beginning with their birth. In this process, the brain constantly develops synaptic links are adjusted with experience and even new links can be formed. Learning takes place as a result of this. This process displays a similar progression in ANNs.

Therefore, ANN is an artificial intelligence technology that is used in applications where there are multiple variables in interaction with each other and which gives successful results in situations where there is mutual interaction (Raol and Mankame, 1996, pp. 48-52).

In the structure of an ANN, there are three layers: namely the input layer accommodating interconnected neurons, the output layer and the hidden layer (Chen and Du, 2009, p. 4076): 
$\checkmark$ The input layer is the first layer enabling the reception of external signals into the ANN. These signals are taken into consideration as independent variables in statistical analyses.

$\checkmark$ The hidden layer that is the second layer is the one which transfers the signals taken from the input layer to the output layer and which does not have any links to the external environment.

$\checkmark$ The output layer that is the last layer enables the transfer of the data to outside. Output variables are used as dependent variables in statistics.

Figure 2 shows model of an artificial neuron. One of the most important factors in ANN is the links, which enable data transfer between neurons. A link that transfers data from a (i) neuron to a $(\mathrm{j})$ neuron also has a weight value $\left(\mathrm{w}_{\mathrm{ji}}\right)$. Weight shows the relative power of values that are to be used as input in a neuron. All links in ANN have varying weight values (Kirkos et al., 2007, pp. 995-1003).

Figure 2: Model of artificial neuron



Source: J.R. Roal and S.S. Mankame, 1996, p. 48

The sum function that affects the structure of an ANN is the function that calculates the net input entering the neuron, which is formalized as follows (Clarence, 1997, pp. 28-31):

$$
O_{j}=f_{j}\left(\sum W_{i j} X_{i}\right)
$$

In this function;

$\mathrm{X}$ : Inputs,

W: Weights,

O: Sum of weights.

The activation (transfer) function that has a role in the structure of an ANN is the function that transforms the data added by weighing to output. While there are some types of this function, the most commonly used sigmoid activation function is formalized as follows:

$$
f(x)=\frac{1}{1+e^{-x}}
$$

In this function;

$f(x) \quad$ : the normalized form of $x$ values

$\mathrm{x} \quad$ : the input value. 
The reason why the sigmoid activation function is commonly used is that this function can produce balanced output in the modeling of both linear and non-linear functions.

After the activation function is calculated, learning takes place; in this respect he activation function helps the formation of output values normalized between 0 and 1 .

The most important determinant of ANN architecture to be used in the solution of a problem is the learning algorithm and the training and learning of ANN are realized with these algorithms. Learning algorithms enables that the ANN can perform the desired behavior and produce the desired output.

For the ANN, which is fed by certain input to produce the desired output, the weights of the links in the structure of the network can be altered and weight values that will enable the production of output can be determined. For the selected algorithm to perform this task sample input is needed. Iteration is performed until the selected learning algorithm produces the desired output and learning takes place when the desired output is produced. Therefore, the main function of learning algorithms is to make adjustment on the weights of an ANN for the production of the desired output (Raol and Mankame, 1996, pp. 51-52).

The main reason why the ANN model is used the current study is that this model was relatively more successful compared to other models in the empirical studies conducted in this field (Ngai et al., 2011; Ravisankar et al., 2011; Y1ld1z and Akkoc, 2009; Kirkos et al., 2007; Kucukkocaoglu et al., 2007).

The variables used in the Beneish (1999) model are adopted as variables in the prediction and assessment of fraud risk in financial statement. There are two basic reasons why the Beneish (1999) model in this study:

- The Beneish (1999) model, unlike the other models, included as independent variables some ratios derived from financial statements and assumed to be indicators of financial information manipulation together with changes occurring in several years in financial statement items formed only with accrual basis.

- Biannual financial statement data are adequate in the formation of the Beneish (1999) model. Therefore, financial statement data of companies for a prolong period are not needed in this model.

In this study, 289 commercial and corporate companies who operate in the real sector and who withdrew commercial credits from banks have been chosen as the sample. In this framework, companies who operate in sectors outside the real sector such as commerce, services, construction and contracting, and finance as well as companies who had sales below 10 million TL were excluded from the research.

In the formation of the research model, the 2007 financial data of the companies have been taken into account. The basic reason for this is that 2007 was not directly influenced by the financial crises of 2000, 2001, 2008 and 2009 in Turkey. In other words, 2007 was a relatively more consistent year.

97 of companies in the context of the research were assumed to have conducted financial statement fraud, and 192 of them were detected not to have done so.

The distinction between companies who did and did not resort to financial statement fraud was based on the following assumption. 
- Companies whose internal credit scoring is rather credible but whose credit loans have been transferred to bad loan account because they could not fulfill their financial obligations in time, thereby being exposed to legal proceedings due to their credit loans (manipulator-1)

- On the contrary, companies whose internal credit scoring is rather credible and who did not have any problems in the repayments of credits were considered to have financial statements with no element of frauds (Control group which is not a manipulator-0).

Of the companies who were assumed not to have resorted to financial statement fraud, there may be some companies who did not have any problems in credit repayment despite financial information manipulation, but were actually manipulator companies. Besides, this condition, as with any model, was taken to be a Type I error in this study.

In addition, of the companies who were assumed to have resorted to financial statement fraud, there may be some companies who did not actually manipulate on financial information but had some issues in credit repayment. This condition was taken to be a Type II error in this study.

The independent variables in this study are basically the same as those in Beneish (1999). However, in these study two variables that yielded significant findings in Kucuksozen and Kucukkocaoglu (2004), namely "Inventories to Sales Ratio" and "Financing Expenses to Sales Ratio", were added as independent variables and the number of independent variables was increased to 10 .

Kucuksozen and Kucukkocaoglu (2004) based the addition of the variables "Inventories to Sales Ratio" and "Financing Expenses to Sales Ratio" which did not exist in Beneish (1999) into the model on the practices of financial statement fraud. Kucuksozen and Kucukkocaoglu (2004) stated that in the examples regarding financial statement fraud in Turkey, practices such as:

- The activation of financing expenses by adding them to inventories, tangible assets, financial assets or other assets instead of recording them in income statement as current year expenses,

- The reflection of general manufacturing expenses into the cost of goods sold or inventories inaccurately based on the intention of the company administration to reveal the profit as lower or higher than it actually is,

- The application and/or adaptation of valuation methods of inventory (LIFO, FIFO, Average Cost) again based on the intention of the administration

are quite common and that the variables "Inventories to Sales Ratio" and "Financing Expenses to Sales Ratio" can be really significant in the detection of fraud risk in financial statements and thus integrated into the model.

In this framework, the independent variables used in the study are stated as: (1) Days' sales in receivables index (DSRI), (2) Gross profit margin index (GMI), (3) Assets quality index (AQI), (4) Depreciation index (DI), (5) Sale, general and administrative expenses index (SGAI), (6) Total accruals to total assets (TATA), (7) Sales growth index (SGI), (8) Leverage index (LVGI), (9) Financing expenses to sales ratio (FES), (10) Inventories to sales ratio (IS). 
The calculation methods for the 10 independent variables in this empirical study are presented in the appendices.

\section{Planning of the Research and ANN Architecture}

The following research plan was used in this empirical study:

- First of all, the above-mentioned variables to be used in the detection of financial statement fraud risk have been calculated using the 2007 financial data for each company. Those companies in the analyses whose financial statement were assumed to be fraudulent were categorized as "1" and those with no sign of fraud were classified as " 0 ". The obtained categorical variable group was included in the analysis as the target variable.

- Secondly, the data set was loaded into the package software named "Alyuda Neuro Intelligence 2.2" and normalized between 0 and 1.

- Thirdly, the ANN architecture to be used in the analysis was decided and the ANN model was determined. In the study, there is an input layer consisting of 10 neurons and an output layer distinguishing between fraudulent and nonfraudulent financial statements. In addition, a hidden layer was formed consisting of 15 neurons with the lowest mean of absolute error squares for train, validation and test data sets. In this framework, an ANN model with 10 inputs, a hidden layer containing 15 neurons and an output layer (10-15-1). In the study, the data from $68 \%$ (197) of 289 companies were determined as the train set, $16 \%(46)$ as the validation set, and $16 \%(46)$ as the test set.

Table 1. Comparative ANN models and best ANN model

\begin{tabular}{|c|c|c|c|c|c|c|c|}
\hline \multicolumn{8}{|c|}{ Architecture Search } \\
\hline \multicolumn{8}{|c|}{ 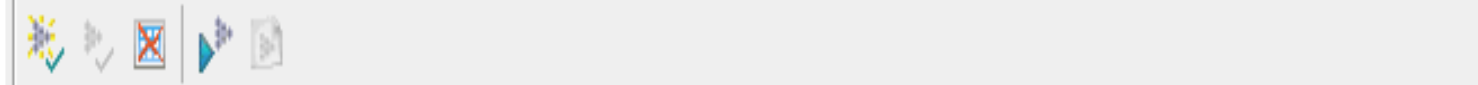 } \\
\hline ID & Architecture & \# of Weights & Fitness & Train Error & Validation Error & Test Error & AIC \\
\hline 3 & {$[10-15-1]$} & 181 & 6,571429 & 0,791878 & 0,804348 & 0,847826 & $-988,008572$ \\
\hline 4 & {$[10-9-1]$} & 109 & 5,111111 & 0,862944 & 0,804348 & 0,804348 & $-1214,302407$ \\
\hline 5 & {$[10-21-1]$} & 253 & 5,75 & 0,80203 & 0,73913 & 0,826087 & $-853,860625$ \\
\hline 6 & [10-18-1] & 217 & 5,111111 & 0,781726 & 0,717391 & 0,804348 & $-906,625846$ \\
\hline 7 & {$[10-12-1]$} & 145 & 5,75 & 0,786802 & 0,782609 & 0,826087 & $-1055,261354$ \\
\hline 8 & {$[10-16-1]$} & 193 & 4,6 & 0,817259 & 0,804348 & 0,782609 & $-989,629038$ \\
\hline 9 & {$[10-13-1]$} & 157 & 6,571429 & 0,766497 & 0,76087 & 0,847826 & $-1013,339914$ \\
\hline & {$[10-14-1]$} & 169 & 5,111111 & 0,791878 & 0,782609 & 0,804348 & $-1012,008572$ \\
\hline
\end{tabular}




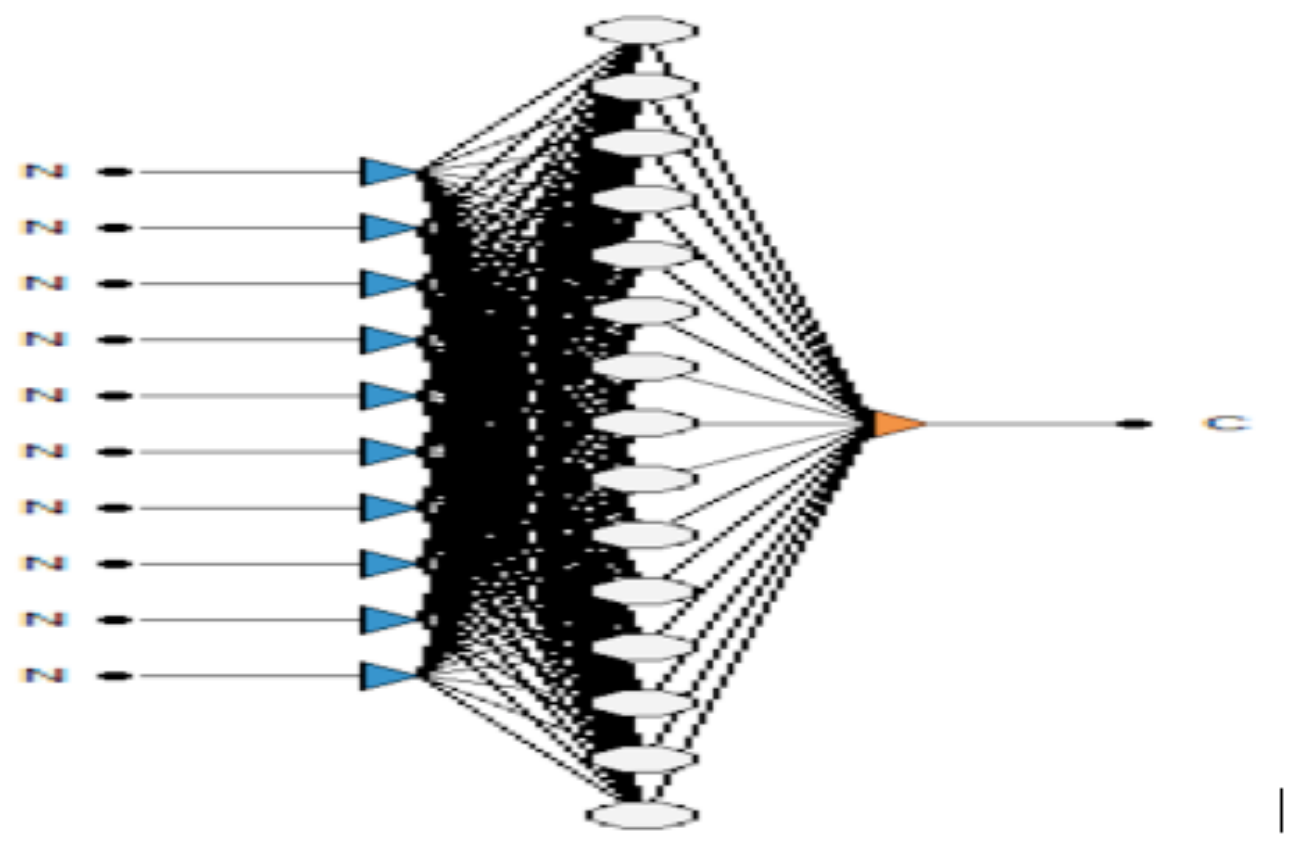

Table 1 shows structure of best ANN model. The structure of the ANN model with 10 input, 15 neurons, 1 hidden layer and 1 output layer which yielded the best findings as a result of various trials is presented in the table 2 .

Table 2. The structure of ANN model

\begin{tabular}{|c|c|c|}
\hline \multicolumn{3}{|l|}{ Active Network } \\
\hline \multicolumn{3}{|c|}{ I Show network image } \\
\hline & & $\because$ \\
\hline \multicolumn{3}{|c|}{ Network Properties } \\
\hline Parameter & Value & \\
\hline Input activation $\mathrm{Fx}$ & Logistic & \\
\hline Output name & HİLE RİSKİ & \\
\hline Output error FX & Sum-of-squares & \\
\hline Output activation FX & Logistic & \\
\hline Classification model & Confidence limits & \\
\hline Accept level & 0,5 & \\
\hline Reject level & 0,5 & \\
\hline
\end{tabular}

Table 2 shows that "Logistic" was used as both input and output activation functions and "Sum-of-squares" was used as the output error function.

- Fourthly, the training of the network was conducted in the framework of the defined ANN architecture. "Quick Propagation" was chosen as the training algorithm since the network structure in which the "Quick Propagation" algorithm was used as the training algorithm yielded good results. Afterwards 5,000 iterations were done for the training of the network. In the mentioned algorithm, the learning ratio was taken to be 0.1 and reiterated to decrease error. 
- Fifthly, the success of the model in predicting fraud risk in financial statements was determined by comparing the findings produced by the trained ANN architecture and real findings.

\section{Research Findings}

In this part of the study, some financial properties of the companies in the scope of the research were presented with respect to manipulator companies and control group companies separately.

Secondly, after comparatively analyzing the distribution of the independent variables with respect to manipulator companies and control group companies, whether these variables create any difference between groups was determined.

Thirdly, the success of the ANN model (10-15-1) developed in the framework of the research plan presented above in predicting fraudulent financial statements was presented.

The properties of manipulator and control group companies concerning some financial indicators are presented in Table 3.

Table 3. Financial properties of firms

\begin{tabular}{|l|r|r|r|r|}
\hline & \multicolumn{2}{|c|}{ Control Group } & \multicolumn{2}{|c|}{ Manipulator Group } \\
\cline { 2 - 5 } & \multicolumn{2}{|c|}{$\mathbf{- 1 9 2}$} & \multicolumn{2}{|c|}{$\mathbf{- 9 7}$} \\
\cline { 2 - 5 } & Mean & Median & Mean & Median \\
\hline Total Ass ets (x 000 TL) & 28.313 & 11.752 & 8.311 & 3.326 \\
\hline Working Capital/Total Assets & 0,18 & 0,16 & $-0,05$ & 0,03 \\
\hline Total De bt/Total Assets & 0,55 & 0,49 & 0,78 & 0,66 \\
\hline Sales Growth & 1,37 & 1,25 & 1,42 & 1,27 \\
\hline Bad Loan (x 000 TL) & - & - & 4.022 & 2.126 \\
\hline Net Profit/Equity & 0,22 & 0,16 & 0,17 & 0,11 \\
\hline
\end{tabular}

When Table 3 is analyzed, it is observed that, as opposed to control group companies the companies who were assumed to have conducted financial statement fraud have: (1) smaller net assets, (2) lower, or even negative, working capital, (3) high leverage ratio and therefore more debts, (4) more rapidly growing sales, (5) bad loans, (6) and lower equity profitability.

In Table 4, it has been shown whether the independent variables used in the analysis created a significant difference between manipulator and control group companies with a t-test. 
Table 4. T-test findings regarding the relationship between independent variables and fraud risk

\begin{tabular}{|c|c|c|c|c|c|c|c|c|c|}
\hline \multirow[b]{2}{*}{ VERIABLES } & \multicolumn{2}{|c|}{ Levene' s Test } & \multicolumn{7}{|c|}{ T-Test } \\
\hline & $\mathbf{F}$ & Sig. & $\mathbf{t}$ & df & Sig.(2-tailed) & Mean & S.D. & Min. & Max. \\
\hline \multirow[b]{2}{*}{ DSRI } & 4,253 & 0,04 & $-1,306$ & 287 & 0,193 & $-0,213$ & 0,163 & $-0,534$ & 0,108 \\
\hline & & & $-1,168$ & 145,413 & 0,245 & $-0,213$ & 0,183 & $-0,574$ & 0,148 \\
\hline \multirow[b]{2}{*}{ GMI } & 0,028 & 0,868 & $-0,732$ & 287 & 0,465 & $-0,059$ & 0,08 & $-0,217$ & 0,099 \\
\hline & & & $-0,663$ & 150,271 & 0,508 & $-0,059$ & 0,089 & $-0,234$ & 0,116 \\
\hline \multirow[b]{2}{*}{ AQ I } & 5,305 & 0,022 & 1,056 & 287 & 0,292 & 0,184 & 0,174 & $-0,159$ & 0,526 \\
\hline & & & 1,271 & 286,079 & 0,205 & 0,184 & 0,144 & $-0,101$ & 0,468 \\
\hline \multirow[b]{2}{*}{$\mathbf{D I}^{* *}$} & 11,351 & 0,001 & $-2,569$ & 287 & 0,011 & $-0,122$ & 0,047 & $-0,215$ & $-0,028$ \\
\hline & & & $-2,296$ & 145,254 & 0,023 & $-0,122$ & 0,053 & $-0,226$ & $-0,017$ \\
\hline \multirow[b]{2}{*}{ SGAI*** } & 2,998 & 0,084 & $-2,016$ & 287 & 0,045 & $-0,105$ & 0,052 & $-0,207$ & $-0,002$ \\
\hline & & & $-1,887$ & 162,36 & 0,061 & $-0,105$ & 0,055 & $-0,214$ & 0,005 \\
\hline \multirow[b]{2}{*}{ LVGI } & 18,887 & 0 & $-1,637$ & 287 & 0,103 & $-0,049$ & 0,03 & $-0,108$ & 0,010 \\
\hline & & & $-1,938$ & 282,802 & 0,054 & $-0,049$ & 0,025 & $-0,099$ & 0,001 \\
\hline \multirow[b]{2}{*}{ TATA* } & 19,634 & 0 & $-5,201$ & 287 & 0,000 & $-0,16$ & 0,031 & $-0,221$ & $-0,100$ \\
\hline & & & $-6,105$ & 280,05 & 0,000 & $-0,16$ & 0,026 & $-0,212$ & $-0,109$ \\
\hline \multirow[b]{2}{*}{ FES } & 7,639 & 0,006 & $-1,384$ & 287 & 0,167 & $-69,595$ & 50,274 & $-168,549$ & 29,358 \\
\hline & & & $-0,983$ & 96,047 & 0,328 & $-69,595$ & 70,827 & $-210,185$ & 70,994 \\
\hline \multirow[b]{2}{*}{ IS } & 19,304 & 0 & $-2,16$ & 287 & 0,032 & $-4626,978$ & 2141,669 & $-8842,347$ & $-411,608$ \\
\hline & & & $-1,533$ & 96 & 0,129 & $-4626,978$ & 3018,279 & $-10618,213$ & 1364,258 \\
\hline \multirow[b]{2}{*}{ SGI } & 1,911 & 0,168 & $-0,612$ & 287 & 0,541 & $-0,049$ & 0,081 & $-0,208$ & 0,109 \\
\hline & & & $-0,591$ & 175,87 & 0,555 & $-0,049$ & 0,083 & $-0,214$ & 0,115 \\
\hline${ }^{*} \mathbf{p}=\mathbf{0 , 0 1}$ & $* * \mathbf{p}=\mathbf{0 , 0 5}$ & $* * * \mathbf{p}=\mathbf{0}, \mathbf{1 0}$ & & & & & & & \\
\hline
\end{tabular}

When Table 4 is analyzed we observe an obvious difference between manipulator and control companies in terms of DI and TATA. Therefore we can state that this variable is significantly effective in the prediction of fraud risk in financial statement fraud $(p<.05)$. The SGAI variable is also significantly influential in the detection of fraud risk $(\mathrm{p}<.10)$.

When the findings in Table 4 are evaluated in terms of DI, similar to findings of Beneish (1999), it is observed that the manipulator companies resorted to financial statement fraud using depreciations in comparison with control companies.

In terms of TATA, the findings reveal that manipulator companies, in contrast with control group companies, conducted financial statement fraud by either increasing their income via accruals or decreasing expenses. This finding is parallel to Beneish (1999) findings.

When the findings in the table are analyzed, parallel to Beneish (1999), in terms of SGAI variable changes in marketing, sales-distribution and general management expenses produced a significant difference between manipulator and control group companies regarding whether they have resorted to financial statement fraud.

As opposed to these findings, no significant difference between manipulator and control group companies was detected in terms of DSRI, GMI, AQI, LVGI, FES, IS and SGI.

The success of the ANN model with 10 input, 15 neurons, 1 hidden layer and 1 output layer (10-15-1) in predicting fraud risk in financial statements as a result of analyses of properties of manipulator and control group companies regarding independent variables are presented in the following tables. 
Table 5. Performance of ANN Model

\begin{tabular}{|l|c|c|c|}
\hline \multicolumn{1}{|c|}{ Data Group } & Fraud (\%) & Non-Fraud(\%) & Total (\%) \\
\hline Training Set & 96,9 & 89,9 & 93,9 \\
\hline Validation Set & 87,5 & 71,4 & 82,6 \\
\hline Test Set & 84,3 & 78,6 & 82,6 \\
\hline Whole Set & 92,7 & 85,6 & 90,3 \\
\hline
\end{tabular}

When Table 5 is analyzed the correct classification ratio (CCR) of the train set for the developed ANN model was found to be $94 \%$. That is, the developed ANN model could correctly predict $62(90 \%)$ of 69 fraudulent financial statements within the train set and $123(96 \%)$ of 128 financial statements without fraud findings. When the table is analyzed it can be seen that the CCR for the validation set is $83 \%$. This means that the ANN model could successfully predict $10(72 \%)$ of 14 fraudulent financial statements in the validation set and $28(88 \%)$ of 32 financial statements without fraud findings. When the table is analyzed it can be seen that the CCR for the test set is $83 \%$. This means that the ANN model could successfully predict $11(79 \%)$ of 14 fraudulent financial statements in the test set and $27(84 \%)$ of 32 financial statements without fraud findings. When the table is analyzed it can be seen that the CCR for the whole set is $90 \%$. This means that the ANN model could successfully predict $83(86 \%)$ of 97 fraudulent financial statements in the whole set and $178(93 \%)$ of 192 financial statements without fraud findings.

To summarize the results presented by the model, the CCR of the detection of financial statement fraud of a new company data in the developed model (10-15-1) can be stated to be $90 \%$.

\section{Conclusions}

In the management of risks overtaken by banks, the accuracy, reliability and quality of information produced in banks gain importance and important investments are made in banks to increase the accuracy, reliability and quality of information generated during the process of loan decision. Especially in the evaluation of commercial loan demands, the primary information sources that banks resort to are financial statements and reports produced within the accounting system by firms.

The financial statements and reports produced in the accounting system can be manipulated to serve personal and corporate purposes by some optional arrangements. The manipulations of financial statements in this manner can cause damage for investors on one hand, employees, creditor companies and public on the other.

On the side of banks, the manipulation of the financial statements and reports of companies who are bank clients due to the fact that these statements and reports cannot truly reflect their financial situations and operational results can cause, on one hand, damage for banks who give loans based on these financial statements and, on the other hand, the ineffective use of limited savings, therefore the occurrence of alternative cost.

As can be seen from some scandalous events experienced in the past, banks suffered billions of dollars of damage because of loans given to companies with fraudulent financial statements. Stakeholders in money and capital markets attached a 
great importance to effective corporate governance which ensure the quality, accuracy and transparency of financial information; however the scandalous events in the past created distrust in financial statements published after auditing on the side of market stakeholders and caused suspicion even for externally audited financial statements.

As a matter of fact, financial statement fraud has come to be hotly debated following these events and recently business world, accounting experts, academics and market makers stipulated serious warnings about financial statement fraud.

The financial statement fraud related events in the past and damages resulting from these events have aroused necessity for early warning systems which will enable the detection financial statement fraud before they happen and various models have been developed towards the prediction of financial statement fraud (Nigai et al., 2011; Ravisankar et al., 2011; Humpherys et al., 2011; Zhou and Kapoor, 2011; Perols and Lougee, 2010; Ata and Seyrek, 2009; Kirkos, 2007; Kucukkocaoglu et al., 2007; Kucuksozen and Kucukkocaoglu, 2004; Spathis, 2004; Spathis, 2002; Beneish, 1999; Beneish, 1997).

In the current study, to develop an ANN model which can foresee and assess fraud risk in financial statements in order to detect fraud risk in financial statements during the evaluation of loans and thereby preventing or decreasing loan risk.

There are a number of studies in the literature conducted on companies which are listed stock exchange towards the prediction of fraudulent financial statements. A vast majority of these studies focus on the prevention of manipulation towards common stock investments.

Nevertheless, the current study is of great difference since the sample of the study was chosen from commercial and corporate bank clients; the analysis was directed at the banking sector; and the model developed in the framework of the study aims to detect manipulations against creditor companies.

In the study, the primary reason for the utilization for the ANN model is that this model created more successful results when compared to other models (logit, probit, UTADIS, decision tree, Bayes etc.) in empirical studies (Ngai et al., 2011; Ravisankar et al., 2011; Y1ldiz and Akkoc, 2009; Kirkos et al., 2007; Kucukkocaoglu et al., 2007) conducted in this field.

10 different variables adopted from Beneish (1999) and Kucuksozen and Kucukkocaoglu (2004) were used to detect financial statement fraud risk. 289 firms who are bank clients were analyzed in the scope of research. 97 of these firms were assumed to have fraudulent financial statements in 2007 fiscal year since they had problems in the repayment of loans. 192 of these firms were chosen as the control group since they had no problems in the repayment of loans in the year 2007. As a result of the statistical analysis, it has been understood that companies with fraudulent financial statements have some features in common. These firms have small net assets, low or even negative operational capital, high leverage ratio, rapidly growing sales, low equity profitability and bad loans. These findings are in line with those of Beneish (1997), Beneish (1999) and Kucuksozen and Kucukkocaoglu (2004).

In manipulation towards banks, total accruals/total assets (TATA) index and depreciation index (DI) variables have yielded significant differences in the detection of fraudulent financial statements. This finding is partially consistent with the literature. 
Some other variables which demonstrated significant differences in the detection of fraudulent financial statements are accounts receivables turnover ratio, growth in receivables and growth in sales (Perols and Lougee, 2010); leverage ratio and return on assets (Ata and Seyrek, 2009); Altman $\mathrm{z}$ score, total debts/total equity ratio, net profit/total assets, total sales/total assets, working capital/total assets and EBIT (Kirkos et al., 2007); receivables index, gross profit margin index, depreciation index, financing expenses/sales, quality of assets index and inventory/sales (Kucuksozen and Kucukkocaoglu, 2004); total debts/total assets, inventory/sales, net profit/net sales and inventory/total assets (Spathis et al., 2004); net profit/total assets and financing expenses/operating expenses (Kucuksozen and Kucukkocaoglu, 2004); inventory/sales, total debts/total assets and Altman z score (Spathis, 2002).

Therefore based on both the findings in the literature and the results obtained from the current study, there is no generally accepted variable set to be used in the detection of fraudulent financial statements.

The reason of the wide variety of variables used in the detection of fraudulent financial statements is that the target and aims of the manipulation differs from company to company and sector to sector.

It has been decided that the ANN model developed in order to forecast and assess fraud in financial statements has good performance and consistent structure. As a matter of fact, the ANN model developed in the framework of the current study has successfully predicted fraud risk in 261 of 289 companies sampled for the study and achieved a success rate of $90 \%$. Therefore the developed ANN model can be considered to have high prediction power.

This finding obtained from the current study presents fairly similar results to the other empirical studies in the literature using ANN models. To illustrate, Ravisankar et al. (2011), Kirkos et al. (2007) and Kucukkocaoglu et al. (2007) predicted fraudulent financial statements with rates of $96 \%, 100 \%$ and $86 \%$ respectively.

In the light of the discussion, to provide the following suggestion for bank authorities to be used in the assessment of commercial and corporate loan demands:

$\checkmark$ Banks make their loan decisions by quantitatively analyzing the financial statements of companies as they are or following limited "debugging operation" based on limited information. However no precautions are taken against fraud risk in financial statements, thereby causing bad loans. For this reason, the ANN model can provide an effective solution for the prevention of commercial and corporate loans based on fraudulent financial statements.

$\checkmark$ In countries where there is a high rate of off-the-record operations, it is extremely difficult to make healthy loan decisions based on financial statements. The fiscal information obtained from companies who are highly engaged in offthe-record operations mostly consist of fiscal data manipulated based on off-therecord operations. Therefore, banks can used the ANN model also to detect companies with a high rate of off-the-record operations.

$\checkmark$ Banks are institutions who have strong databases because of investments done in information processing technologies. Therefore, the ANN model can be an efficient method to be used in the prediction of fraud risk in financial statement via interfaces and software which will be added on to their credit scoring modules. 
$\checkmark$ Banks will be able to predict fraud risk in financial statements using the developed ANN model and used the findings presented by the model in their loan decisions. In other words, this model will help the bank authorities in their decision not to give loans to a company with fraudulent financial statement and prevent any future loan risk. Banks can also use the developed ANN model in decisions related to the limit due date and price of loans.

$\checkmark$ If the ANN model reflects fraud findings in the financial statements of a company, the decision makers for loans in a bank can take this finding into consideration and decide not to give loans to that company. If there are slight indications that there is fraud in the financial statements of the company, the decision makers in the bank can offer low limits, short due dates and high prices for the loans.

$\checkmark$ Therefore the developed ANN model will discipline financial statements of companies by ensuring the consideration of fraud risk in financial statements by banks in their loan decisions.

$\checkmark$ On the side of banks, the developed ANN model will create a more reliable and accurate lending process by highlighting fraud risk in financial statements for loan decisions.

The following suggestion is provided for commercial and corporate companies who are bank clients:

> Companies should discipline their financial statements in order to be able to acquire loans from banks with high limits, long due dates and low prices and avoid practices that may lead to manipulations in financial statements.

The following are suggestions for further research based on the findings of the current study:

* The sample of the study consists of commercial and corporate clients who are not listed in the stock exchange and who have sales over 10 million TL. Therefore, this study presents an important projection in that it provides a different perspective and guides other researchers who will conduct studies concerning the detection of manipulations done by listed bank clients, micro and small size companies whose sales is below 10 million TL or who operate in sectors other than the manufacturing sector.

* Besides, further studies can be conducted which will include different and more various variables to increase the prediction power and representativeness of models which can foresee and assess manipulations towards creditor institutions.

* This artificial intelligence technology used in the detection of manipulations against creditor institutions can be combined with fuzzy logic to obtain more comprehensive and healthier results that are based on some assumptions. 


\section{References}

Albrecht, S., Romney, M. (1986). "Red-Flagging Management: a Validation", Advances in Accounting, Vol. 3, pp.32-33.

Apastolou, B., Hassell, J. M., Webber, S. A. (2001). "Management Fraud Risk Factors: Ratings by Forensic Experts", the CPA Journal, 71 (10), pp. 48-52

Arens, A., Loebbecke J. (1994). Auditing: An Integrated Approach, 6th Ed, Englewood Cliffs, and NJ: Prentice-Hall.

Ata, H. A., Seyrek, İ. H. (2009). "The Use of Data Mining Techniques in Detecting Fraudulent Financial Statements: An Application on Manufacturing Firms", Süleyman Demirel Üniversitesi İktisadi ve İdari Bilimler Fakültesi Dergisi, Cilt: 14, Say1: 2, ss.157-170

BDDK, (2013). Türk Bankacılık Sektörü Genel Görünümü, BDDK Yayınları, İstanbul

Beasley, M. (1996). "An Empirical Analysis of the Relation Between Board of Director Composition and Financial Statement Fraud", Accounting Review, 71(4), pp.44366.

Bell, T., Szykowny, S., Willingham, J. (1993). "Assessing the Likelihood of Fraudulent Financial Reporting: a Cascaded Logic Approach”, Working Paper, KPMG Peat Marwick, Montvale, NJ.

Beneish, M. D. (1997). "Detecting GAAP Violation: Implications for Assessing Earnings Management Among Firms with Extreme Financial Performance", Journal of Accounting and Public Policy, Vol:16, No: 3, pp. 271-309

Beneish, M. D. (1999). "The Detection of Earnings Manipulation”, Financial Analysts Journal, Vol:55, No:5, pp. 24-36

Bologna, G., Lindquist R., Wells J. (1996). The Accountant's Handbook of Fraud and Commercial Crime. New York: John Wiley.

Braiotta, L. (2004). Audit Committee Handbook, John Wiley \& Sons, New Jearsy/USA.

Chen, W. S., Du, Y. K. (2009). "Using Neural Networks and Data Mining Techniques for the Financial Distress Prediction Model". Expert Systems with Applications, Vol: 36, pp. 4075-4086

Clarence, N., Tan, W. (1997). An Artificial Neural Networks Primer with Financial Applications Examples in Financial Distress Predictions and Foreign Exchange Hybrid Trading System, Bond University, Avusturalya.

Davia, H., Coggins, P., Wideman, J., Kastantin, J. (1992). Management Accountant's Guide to Fraud Discovery and Control. New York: John Wiley.

Elliott, R. K., Willingham, J. J. (1980). Management Fraud: Detection and Deterrence, Petrocelli Boks, New York.

Fausett, L. (1994). Fundamentals of Neural Networks: Architectures, Algorithms and Applications, Prentice Hall, New York.

Green, B. P., Choi, J. H. (1997). "Assessing the Risk of Management Fraud Through Neural Network Technology", Auditing: A Journal of Practice and Theory, 16(1), pp. 14-28. 
Hoffman, V. B. (1997). "Discussion of the Effects of SAS No. 82 on Auditors' Attention to Fraud Risk-Factors and Audit Planning Decisions", Journal of Accounting Research, 35(5), pp. 99-104.

Hollman, V. P., Patton, J. M. (1997). "Accountability, the Dilution Effect and Conservatism in Auditors' Fraud Judgments", Journal of Accounting Research, 35(2), pp. 227-37.

Humpherys, S. L., Moffitt, K. C., Burns, M. B., Burgoon, J. K., Felix, W. F. (2011). "Identification of Fraudulent Financial Statements Using Linguistic Credibility Analysis", Decision Support Systems, Vol. 50, pp. 585-594

Jackson, L. M. (1999). Efforts to Combat Health Care Fraud: A Study of NYSE Listed Health Care Service Companies, Pace University, UK.

Kirkos, E., Spathis, C., Monolopoulos, Y. (2007). "Data Mining Techniques for The Detection of Fraudulent Financial Statements". Expert Systems with Applications, Vol: 32, pp. 995-1003

KPMG, (2004). Fraud Survey, KPMG, Australia.

Küçükkocaoğlu, G., Küçüksözen, C. (2004). "Gerçeğe Aykırı Finansal Tabloların Ortaya Çıkarılması: IMKB Şirketleri Üzerine Ampirik Bir Çalışma”, Muhasebe ve Finansman Dergisi.

Küçükkocaoğlu, G., Benli, Y. K., Küçüksözen, C. (2007). "Finansal Bilgi Manipülasyonunun Tespitinde Yapay Sinir Ağı Modelinin Kullanımı”, İMKB Dergisi, Y11:9, Say1:36, İstanbul, ss.1-30

Küçüksözen, C., Küçükkocaoğlu, G. (2004). "Finansal Bilgi Manipülasyonu: İMKB Şirketleri Üzerine Aprik Bir Çalışma”, MÖDAV Uluslararası Muhasebe Konferansı'nda Sunulan Tebliğ, 03-05 Kasım 2004, İstanbul, ss.1-58

Loebbecke, J., Eining, M., Willingham, J. (1989). “Auditor's Experience with Material Irregularities: Frequency, Nature, and Detectability", Auditing: A Journal of Practice and Theory, Vol. 9, pp. 1-28.

Madura, J. (2004). What Every Investor Needs to Know About Accounting Fraud, McGraw Hill Company, New Jearsy.

McKee, T. E. (2005). Earnings Management: An Executive Perspective, Thomson Corporation, USA.

Ngai, E. W. T., Hu, Y., Wong, Y. H., Chen, Y., Sun, X. (2011). "The Application Of Data Mining Techniques in Financial Fraud Detection: A Classification Framework and an Academic Review of Literature", Decision Support Systems, Vol. 50, pp. 559-569

Palmrose, Z. (1987). "Litigation and Independent Auditors: the Role of Business Failures and Management Fraud", Auditing: A Journal of Practice and Theory, 6(2), pp. 90-102.

Perols, J. L., Lougee, B. A. (2010). “The Relation Between Earnings Management and Financial Statement Fraud", Advances in Accounting, Incorporating Advances in International Accounting, pp. 1-15 
Ravisankar, P., Ravi, V., Rao, G. R., Bose, I. (2011). "Detection of Financial Statement Fraud and Feature Selection Using Data Mining Techniques", Decision Support Systems, Vol. 50, pp. 491-500

Raol, J. R, Mankame, S. S. (1996). “Artificial Neural Network; A Brief Introduction”, Resonance, February, pp. 47-54

Rezaee, Z. (2002). Financial Statement Fraud; Prevention and Detection, John Wiley \& Sons, Inc., New York.

Rezaee, Z. (2005). "Causes, Consequences and Deterence of Financial Statement Fraud", Critical Perspectives on Accounting, 16 (3), pp.277-298.

Rud, O. P. (2001). Data Mining Cookbook; Modeling Data for Marketing, Risk, and Customer Relationship Management, John Wiley \& Sons, Inc., New York.

Schilit, H. (1993). Financial Shenanigans: How to Detect Accounting Gimmicks and Fraud in Financial Reports. New York: McGraw-Hill.

Spathis, C. T. (2002). "Detecting False Financial Statements Using Published Data: Some Evidence From Greece", Managerial Auditing Journal, Vol: 17, No: 4, pp. 179-191

Spathis, C. T., Doumpos, M., Zopounidis, C. (2004). "Detecting Falsified Financial Statements: A Comparative Study Using Multicriteria Analysis and Multivariate Statistical Techniques", The European Accounting Review, Vol: 11, No: 3, pp. 509-535

Stice, J. (1991). "Using Financial and Market Information to Identify Pre-engagement Market Factors Associated with Lawsuits Against Auditors", Accounting Review, 66(3), pp. 516-33.

Ugrin, J. C., Odom, M. D. (2010). "Exploring Sarbanes-Oxley's Effect on Attitudes, Perceptions of Norms, and Intentions to Commit Financial Statement Fraud From A General Deterrence Perspective”, J. Account Public Policy, Vol. 29, ss. 439458

Wells, J. T. (2004). Corporate Fraud Handbook; Prevention and Detection, John Wiley\&Sons, New Jersey.

Yıldız, B., Akkoç, S. (2009). "Banka Finansal Başarısızlıklarının Sinirsel Bulanık Ağ Yöntemi ile Öngörüsü”, BDDK Bankacılık ve Finansal Piyasalar, Cilt: 3, Sayı: 1, ss. $9-36$

Zhou, W., Kappor, G. (2011). "Detecting Evolutionary Financial Statement Fraud", Decision Support Systems, Vol. 50, pp. 570-575

Zimbelman, M. F. (1997). "The Effects of SAS No. 82 on Auditors' Attention to Fraud Risk Factors and Audit Planning Decisions", Journal of Accounting Research, 35(5), pp. 5-9. 


\section{Appendix}

$$
\begin{aligned}
& \text { USQ }=\frac{\frac{\text { TU. Rex }}{\text { Gros!: Salcti: }}}{\text { Tru. Rocr-1 }}
\end{aligned}
$$

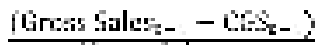

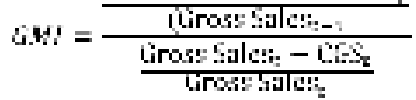

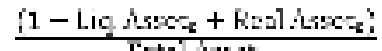

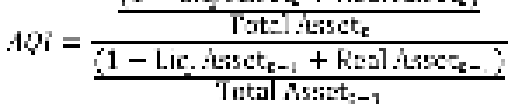

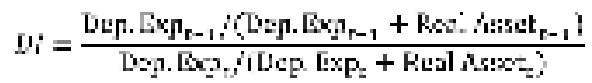

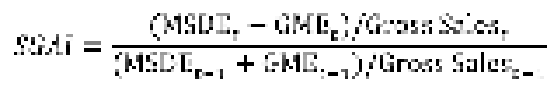



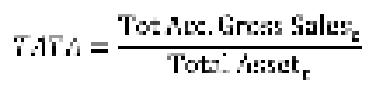



$$
\begin{aligned}
& S=\frac{\text { maciscoiss }}{\text { Salas }}
\end{aligned}
$$

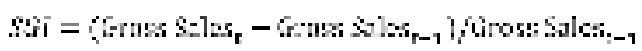

(DSRI): Days' sales in receivables index, (GMI); Gross profit margin index, (AQI): Asset quality index, (DI): Depreciation index, (SGAI): Sale, general and administrative expenses index, (LVGI): Leverage index, (TATA): Total accrual/total asset rate, (FES): Financing Expenses to Sales, (IS): Inventories to Sales, (SGI): Sales growing index 


\section{Uğurlu - Ş. Sevim 7/1 (2015) 60-89}

\begin{tabular}{|c|c|c|c|c|c|c|c|c|c|c|c|c|c|c|}
\hline & \multicolumn{14}{|c|}{ Output of ANN Model } \\
\hline FIRMS & DSRI & GMI & AQI & DI & SGAI & LVGI & TATA & FES & IS & SGI & TAR & OUTPU & PREDICT & FRAUD RISK \\
\hline 1 & 1,17 & 0,82 & 0,90 & 1,04 & 1,12 & 0,91 & $-0,11$ & 1,24 & 0,98 & 1,46 & 1 & 0 & Wrong & 0,344637 \\
\hline 2 & 0,54 & 1,34 & 1,01 & 0,98 & 0,82 & 1,00 & $-0,24$ & 0,39 & 1,03 & 1,12 & 1 & 0 & Wrong & 0,175965 \\
\hline 3 & 2,31 & 1,40 & $-0,34$ & 0,99 & 0,84 & 1,13 & $-0,49$ & 0,57 & 2,14 & 1,34 & 1 & & OK & 0,927575 \\
\hline 4 & 1,33 & 1,12 & 1,28 & 0,84 & 1,02 & 1,03 & 0,00 & 0,47 & 0,89 & 1,55 & 1 & & OK & 0,998854 \\
\hline 5 & 1,26 & 0,83 & 0,83 & 1,43 & 1,04 & 0,99 & $-0,03$ & 1,11 & 0,75 & 1,07 & 1 & & OK & 0,992104 \\
\hline 6 & 2,19 & 2,04 & 0,80 & 1,26 & 0,12 & 0,92 & $-0,21$ & 0,12 & 0,51 & 1,31 & 1 & & OK & 0,918489 \\
\hline 7 & 1,15 & 0,96 & 0,98 & 1,27 & 0,99 & 0,86 & $-0,08$ & 1,16 & 1,23 & 1,30 & 1 & 0 & Wrong & 0,263786 \\
\hline 8 & 1,28 & 1,16 & 1,18 & 0,67 & 1,09 & 1,02 & $-0,03$ & 1,60 & 0,72 & 1,44 & 1 & & $\mathrm{OK}$ & 0,955624 \\
\hline 9 & 1,27 & 0,77 & 0,63 & 3,55 & 1,18 & 0,85 & $-0,05$ & 1,82 & 2,52 & 1,23 & 1 & & OK & 0,999146 \\
\hline 10 & 0,63 & 1,09 & 1,09 & 0,90 & 0,33 & 0,93 & $-0,06$ & 0,49 & 0,25 & 5,17 & 1 & & OK & 0,998184 \\
\hline 11 & 0,99 & 1,24 & 1,12 & 1,21 & 0,95 & 0,85 & $-0,39$ & 0,41 & 0,30 & 1,11 & 1 & 0 & Wrong & 0,048584 \\
\hline 12 & 0,96 & 0,98 & $-1,84$ & 1,19 & 1,37 & 1,04 & $-0,10$ & 1,20 & 0,97 & 1,18 & 1 & & OK & 0,797169 \\
\hline 13 & 1,13 & 0,93 & 1,06 & 0,96 & 0,61 & 0,90 & $-0,08$ & 0,85 & 0,02 & 2,29 & 1 & 1 & OK & 0,942332 \\
\hline 14 & 0,92 & 0,98 & 1,08 & 0,90 & 0,98 & 0,95 & $-0,37$ & 1,33 & 1,39 & 0,86 & 1 & 0 & Wrong & 0,091424 \\
\hline 15 & 1,13 & 0,90 & 1,01 & 0,90 & 1,87 & 1,01 & $-0,05$ & 0,78 & 0,98 & 1,21 & 1 & & $\mathrm{OK}$ & 0,988299 \\
\hline 16 & 0,84 & 0,90 & 1,08 & 0,90 & 1,09 & 1,00 & $-0,15$ & 1,52 & 1,47 & 1,03 & 1 & & $\mathrm{OK}$ & 0,698955 \\
\hline 17 & 1,19 & 1,01 & 1,06 & 0,63 & 0,93 & 0,97 & $-0,01$ & 1,62 & 0,85 & 1,28 & 1 & & OK & 0,927509 \\
\hline 18 & 0,15 & 1,47 & 0,88 & 1,27 & 2,18 & 1,17 & $-0,05$ & 0,60 & 3,21 & 0,88 & 1 & 1 & $\mathrm{OK}$ & 0,999588 \\
\hline 19 & 1,63 & 0,85 & 1,14 & 0,93 & 1,61 & 1,03 & $-0,05$ & 2,44 & 3,04 & 0,76 & 1 & & OK & 0,990852 \\
\hline 20 & 1,02 & 1,02 & 0,26 & 1,60 & 1,17 & 1,08 & $-0,04$ & 1,52 & 231678,54 & 1,55 & 1 & 1 & OK & 0,99905 \\
\hline 21 & 1,00 & 0,89 & 1,03 & 0,91 & 0,95 & 1,00 & $-0,12$ & 1,31 & 1,18 & 1,03 & 1 & & OK & 0,827115 \\
\hline 22 & 6,78 & 1,04 & 3,11 & 1,10 & 0,67 & 1,15 & $-0,01$ & 0,84 & 0,80 & 1,61 & 1 & & $\mathrm{OK}$ & 0,946201 \\
\hline 23 & 1,19 & 0,41 & 0,95 & 0,58 & 2,04 & 0,92 & $-0,01$ & 7,94 & 3,68 & 1,17 & 1 & & OK & 0,996203 \\
\hline 24 & 3,35 & 0,94 & $-3,62$ & 0,88 & 1,02 & 1,09 & $-0,26$ & 1,30 & 5,48 & 1,13 & 1 & & OK & \\
\hline 25 & 1,31 & 0,91 & 2,14 & 0,61 & 1,33 & 1,01 & $-0,05$ & 2,03 & 2,02 & 0,82 & 1 & 1 & OK & 0,913006 \\
\hline 26 & 0,97 & 1,39 & 0,61 & 1,29 & 0,23 & 0,84 & $-0,09$ & 1,26 & 0,52 & 1,21 & 1 & 0 & Wrong & 0,126303 \\
\hline 27 & 1,02 & 1,17 & 0,62 & 1,31 & 1,05 & 1,12 & $-0,36$ & 0,89 & 0,72 & 1,10 & 1 & & OK & 0,755909 \\
\hline 28 & 1,03 & 1,04 & 3,04 & 0,64 & 1,03 & 0,58 & $-0,13$ & 1,12 & 0,81 & 1,74 & 1 & & OK & 0,85608 \\
\hline 29 & 1,17 & 1,21 & 1,02 & 0,96 & 0,92 & 1,03 & $-0,03$ & 1,21 & 0,84 & 1,27 & 1 & & IOK & 0,937546 \\
\hline 30 & 0,63 & 0,90 & 1,15 & 0,85 & 1,64 & 0,94 & \begin{tabular}{|c|} 
\\
\end{tabular} & 0,65 & 2,37 & 0,61 & 1 & & IOK & 0,931034 \\
\hline 31 & 0,55 & 0,89 & 1,09 & 0,70 & 1,02 & 0,87 & $-0,09$ & 1,20 & 1,61 & 1,00 & 1 & 0 & Wrong & 0,290579 \\
\hline 32 & 1,53 & 0,82 & 0,54 & 1,55 & 0,85 & 0,89 & $-0,01$ & 2,02 & 0,75 & 0,80 & 1 & 1 & $1 \mathrm{OK}$ & 0,798206 \\
\hline 33 & 0,87 & 1,38 & 0,90 & 0,97 & 0,87 & 1,10 & \begin{tabular}{|l|}
$-0,53$ \\
\end{tabular} & 1,24 & 0,96 & 1,14 & 1 & 1 & IOK & 0,905701 \\
\hline 34 & 1,72 & 1,32 & 1,10 & 0,88 & 1,05 & 0,90 & $-0,07$ & 0,54 & 0,76 & 1,13 & 1 & 0 & Wrong & 0,297783 \\
\hline 35 & 0,90 & 0,62 & 0,95 & 0,83 & 0,91 & 1,02 & $-0,01$ & 1,26 & 0,79 & 1,53 & 1 & 1 & OK & 0,784115 \\
\hline 36 & 10,19 & 4,79 & 1,12 & 2,01 & 0,87 & 0,91 & 0,00 & 0,94 & 2,18 & 1,71 & 1 & & IOK & 0,999809 \\
\hline 37 & 1,37 & 0,88 & 1,16 & 0,96 & 1,15 & 1,22 & $-0,30$ & 1,17 & 0,67 & 0,96 & 1 & & IOK & 0,843518 \\
\hline 38 & 1,07 & 1,19 & 1,15 & 1,12 & 0,86 & 1,04 & $-0,15$ & 0,82 & 1,45 & 1,86 & 1 & & $\mathrm{OK}$ & 0,944972 \\
\hline 39 & 1,90 & 0,79 & $-0,27$ & 1,15 & 1,14 & 1,23 & $-0,12$ & 1,87 & 2,61 & 1,21 & 1 & 1 & $1 \mathrm{OK}$ & 1 \\
\hline 40 & 0,50 & 0,46 & $-2,18$ & 0,92 & 1,58 & 1,15 & $-0,09$ & 2,72 & 39039,10 & 1,72 & 1 & & IOK & 1 \\
\hline 41 & 0,80 & 0,70 & 0,97 & 1,11 & 1,40 & 0,96 & $-0,07$ & 1,22 & 1,15 & 1,13 & 1 & & IOK & 0,959963 \\
\hline 42 & 0,56 & 0,75 & 0,94 & 1,84 & 1,24 & 0,97 & $-0,02$ & 4,80 & 1,72 & 1,56 & 1 & 1 & IOK & 0,99818 \\
\hline 43 & 0,72 & 1,18 & 0,95 & 1,00 & 0,92 & 1,04 & $-0,09$ & 0,84 & 1,55 & 1,43 & 1 & 1 & $1 \mathrm{OK}$ & 0,743612 \\
\hline 44 & 1,24 & 1,12 & 1,22 & 0,69 & 1,19 & 1,10 & $-0,18$ & 0,81 & 1,12 & 1,51 & 1 & & IOK & 0,786309 \\
\hline 45 & 1,14 & 0,80 & 1,02 & 0,91 & 1,03 & 1,64 & $-0,03$ & 1,84 & 0,62 & 1,26 & 1 & & $\mathrm{OK}$ & 0,976376 \\
\hline 46 & 1,00 & 1,09 & 1,01 & 0,90 & 0,97 & 1,04 & $-0,06$ & 1,79 & 1,02 & 1,21 & 1 & & IOK & 0,918893 \\
\hline 47 & 1,53 & 1,04 & 1,15 & 1,13 & 0,98 & 0,99 & $-0,07$ & 2,03 & 1,21 & 1,24 & 1 & 1 & OK & 0,949978 \\
\hline 48 & 0,92 & 0,63 & 0,83 & 1,50 & 1,32 & 0,98 & $-0,10$ & 2,43 & 2,05 & 0,90 & 1 & 1 & $\mathrm{OK}$ & 0,994765 \\
\hline 49 & 1,37 & 1,12 & 1,05 & 0,96 & 0,67 & 0,97 & $-0,25$ & 1,93 & 0,66 & 1,32 & 1 & 1 & $\mathrm{OK}$ & 0,535281 \\
\hline 50 & 1,76 & 1,17 & 0,90 & 0,97 & 0,87 & 1,13 & $-0,93$ & 2,17 & 1,91 & 0,57 & 1 & 0 & Wrong & 0 \\
\hline 51 & 0,56 & 0,48 & 1,49 & 0,75 & 1,40 & 1,07 & $-0,15$ & 2,37 & 1,37 & 1,56 & 1 & & IOK & 0,945687 \\
\hline 52 & 0,78 & 0,88 & 0,95 & 0,89 & 0,80 & 0,91 & $-0,03$ & 1,23 & 0,29 & 1,75 & 1 & & $\mathrm{O} O \mathrm{~K}$ & 0,623246 \\
\hline 53 & 0,23 & 0,82 & 1,02 & 1,01 & 1,32 & 1,03 & $-0,22$ & 1,86 & 1,78 & 0,85 & 1 & & $\mathrm{OK}$ & 0,616865 \\
\hline 54 & 0,98 & 0,97 & 1,06 & 0,87 & 0,96 & 1,46 & $-0,10$ & 1,26 & 1,19 & 1,36 & 1 & & $1 \mathrm{OK}$ & 1 \\
\hline 55 & 0,92 & 0,89 & 0,72 & 1,55 & 0,68 & 1,13 & $-0,03$ & 2,75 & 0,83 & 1,59 & 1 & 0 & Wrong & 0,002363 \\
\hline 56 & 1,15 & 1,12 & 0,60 & 1,40 & 0,91 & 1,23 & $-0,20$ & 1,19 & 1,29 & 1,35 & 1 & 1 & $\mathrm{OKK}$ & 0,991168 \\
\hline 57 & 0,73 & 0,56 & 0,82 & 1,02 & 1,42 & 1,05 & $-0,70$ & 2,92 & 0,80 & 1,32 & 1 & 1 & $\mathrm{OKK}$ & 0,980851 \\
\hline 58 & 0,90 & 0,57 & $-0,96$ & 0,87 & 1,09 & 0,97 & $-0,11$ & 1,06 & 1,56 & 0,99 & 1 & 0 & Wrong & 0,010981 \\
\hline 59 & 1,43 & 1,09 & 1,64 & 1,03 & 0,69 & 1,04 & $-0,10$ & 1,97 & 2,60 & 1,80 & 1 & 0 & Wrong & 0,217297 \\
\hline
\end{tabular}




\section{Uğurlu - Ş. Sevim 7/1 (2015) 60-89}

\begin{tabular}{|c|c|c|c|c|c|c|c|c|c|c|c|c|c|}
\hline 60 & 0,65 & 1,55 & 1,05 & 0,97 & 0,57 & 1,09 & $-0,27$ & 0,78 & 1,03 & 1,56 & 1 & \begin{tabular}{l|l}
1 & $\mathrm{OK}$ \\
\end{tabular} & 0,902022 \\
\hline 61 & 1,31 & 1,30 & 1,41 & 0,77 & 0,94 & 0,84 & $-0,33$ & 0,14 & 0,51 & 1,91 & 1 & \begin{tabular}{l|l|}
1 & $O K$ \\
\end{tabular} & 0,932671 \\
\hline 62 & 0,64 & 1,03 & 1,02 & $\begin{array}{ll}0,81 \\
\end{array}$ & 0,85 & 1,00 & $-0,05$ & 0,27 & 0,54 & 1,81 & 1 & \begin{tabular}{l|l|}
1 & $O K$ \\
\end{tabular} & 0,925365 \\
\hline 63 & 1,08 & 1,13 & 1,27 & 0,84 & 0,92 & 1,07 & $-0,14$ & 0,92 & 0,81 & 1,25 & 1 & \begin{tabular}{l|l|}
1 & $O K$ \\
\end{tabular} & 0,973302 \\
\hline 64 & 1,95 & 0,90 & 0,93 & 0,61 & 3,20 & 1,01 & $-0,01$ & 1,26 & 1,36 & 1,27 & 1 & \begin{tabular}{l|l} 
& $\mathrm{OK}$ \\
\end{tabular} & 0,999148 \\
\hline 65 & 0,60 & 0,99 & 1,05 & 0,72 & 1,42 & 1,05 & $-0,08$ & 5,37 & 3,56 & 1,72 & 1 & $10 \mathrm{OK}$ & 0,829024 \\
\hline 66 & 1,70 & 0,24 & 0,88 & 1,30 & 1,16 & 1,08 & $-0,07$ & 7,44 & 1,67 & 1,01 & 1 & 1 OK & 0,949633 \\
\hline 67 & 1,16 & 0,86 & 0,61 & 1,31 & 0,67 & 0,97 & $-0,08$ & 0,95 & 0,52 & 1,91 & 1 & \begin{tabular}{l|l|}
1 & $O K$ \\
\end{tabular} & 0,549979 \\
\hline 68 & 1,14 & 1,28 & 1,05 & 1,02 & 0,96 & 1,02 & $-0,11$ & 1,16 & 0,85 & 1,34 & 1 & \begin{tabular}{l|l}
1 & $\mathrm{OK}$ \\
\end{tabular} & 0,584564 \\
\hline 69 & 0,96 & 0,93 & 0,88 & 1,04 & 2,02 & 1,01 & $-0,04$ & 5,35 & 2,78 & 0,56 & 1 & \begin{tabular}{l|l|}
1 & $O K$ \\
\end{tabular} & 0,910387 \\
\hline 70 & 0,73 & 0,95 & 0,96 & 1,02 & 0,98 & 1,07 & $-0,06$ & 1,95 & 0,96 & 1,33 & 1 & \begin{tabular}{l|l}
1 & $\mathrm{OK}$ \\
\end{tabular} & 0,592779 \\
\hline 71 & 1,45 & 0,41 & 0,91 & 0,00 & 2,07 & 1,03 & 0,00 & 6871,51 & 3,52 & 3,20 & 1 & \begin{tabular}{l|l|l}
1 & $O K$ \\
\end{tabular} & 0,7999006 \\
\hline 72 & 0,06 & 0,70 & $-1,69$ & 1,68 & 1,24 & 0,99 & $-0,30$ & 0,70 & 1,74 & 1,39 & 1 & \begin{tabular}{l|l|}
1 & $O K$ \\
\end{tabular} & 0,899106 \\
\hline 73 & 0,68 & 0,52 & 1,52 & 0,75 & 0,69 & 0,98 & $-0,05$ & 0,72 & 0,75 & 1,62 & 1 & 1 OK & 0,987564 \\
\hline 74 & 1,67 & 1,11 & 0,76 & 1,75 & 0,93 & 1,22 & $-0,08$ & 1,05 & 1,00 & 1,24 & 1 & \begin{tabular}{l|l|}
1 & $O K$ \\
\end{tabular} & 0,999414 \\
\hline 75 & 1,15 & 0,86 & 0,88 & 1,10 & 0,83 & 1,09 & $-0,41$ & 1,38 & 0,60 & 1,36 & 1 & \begin{tabular}{l|l|}
1 & $O K$ \\
\end{tabular} & 0,867517 \\
\hline 76 & 1,03 & 1,00 & 0,14 & 1,66 & 1,03 & 1,35 & $-0,10$ & 1,72 & 1,00 & 1,31 & 1 & 1 |OK & \\
\hline 77 & 1,06 & 0,92 & 0,94 & 0,96 & 1,49 & 1,06 & $-0,02$ & 1,56 & 1,19 & 1,12 & 1 & \begin{tabular}{l|l|l|}
1 & $O K$ \\
\end{tabular} & 0,840606 \\
\hline 78 & 1,93 & 0,77 & 0,86 & 1,11 & 1,02 & 0,94 & 0,00 & 1,49 & 1,24 & 0,90 & 1 & \begin{tabular}{l|l|}
1 & $O K$ \\
\end{tabular} & 0,982542 \\
\hline 79 & 0,93 & 0,79 & 0,92 & 0,65 & 1,32 & 0,90 & $-0,06$ & 1,98 & 1,37 & 1,08 & 1 & \begin{tabular}{l|l|}
0 & Wrong \\
\end{tabular} & 0,314315 \\
\hline 80 & 1,32 & 0,36 & 0,51 & 2,72 & 3,00 & 0,91 & $-0,01$ & 14,25 & 0,71 & 1,09 & 1 & \begin{tabular}{l|l|}
1 & $O K$ \\
\end{tabular} & 0,99958 \\
\hline 81 & 1,08 & 0,57 & 0,52 & 1,05 & 0,97 & 1,05 & $-0,50$ & 2,63 & 1,41 & 0,94 & 1 & 1 OK & 0,916884 \\
\hline 82 & 1,32 & 0,95 & 1,28 & 0,78 & 1,42 & 1,07 & $-0,07$ & 1,78 & 1,47 & 0,98 & 1 & 1 OK & 0,948818 \\
\hline 83 & 1,14 & 0,61 & 0,98 & 0,80 & 1,58 & 0,85 & 0,00 & 5,22 & 4,55 & 0,99 & 1 & \begin{tabular}{l|l} 
& $\mathrm{OK}$ \\
\end{tabular} & 0,758543 \\
\hline 84 & 0,36 & 0,23 & 0,88 & 0,00 & 1,37 & 0,63 & 0,00 & 44,24 & 178075,87 & 3,13 & 1 & \begin{tabular}{l|l}
1 & $O K$ \\
\end{tabular} & 0,876055 \\
\hline 85 & 1,56 & 0,97 & 1,58 & $\begin{array}{ll}0,95 \\
\end{array}$ & 1,29 & 0,98 & $-0,32$ & 0,91 & 0,62 & 1,32 & 1 & \begin{tabular}{l|l|}
1 & $O K$ \\
\end{tabular} & 0,670214 \\
\hline 86 & 3,25 & 0,89 & 1,19 & 1,22 & 1,00 & 1,01 & $-0,32$ & 1,48 & 1,51 & 1,63 & 1 & \begin{tabular}{l|l|}
1 & $O K$ \\
\end{tabular} & 0,884026 \\
\hline 87 & 0,77 & $-4,50$ & $-0,37$ & 0,97 & 0,58 & 1,08 & $-0,64$ & 0,24 & 0,59 & 4,21 & 1 & 0 Wrong & 0 \\
\hline 88 & 0,02 & 2,47 & 0,37 & 1,26 & 0,48 & 1,03 & 0,00 & 0,28 & 0,24 & 3,62 & 1 & 1 OK & 0,892471 \\
\hline 89 & 0,80 & 2,30 & 0,40 & 1,01 & 1,01 & 1,42 & $-0,18$ & 2,92 & 3,25 & 0,65 & 1 & 1 OK & 0,999973 \\
\hline 90 & 1,35 & 1,22 & 1,17 & 1,45 & 1,07 & 1,09 & $-0,09$ & 1,33 & 1,11 & 2,06 & 1 & \begin{tabular}{l|l|}
1 & $O K$ \\
\end{tabular} & 0,877383 \\
\hline 91 & 0,84 & 2,05 & 1,04 & 1,21 & 0,53 & 1,04 & $-0,05$ & 3,75 & 1,79 & 2,60 & 1 & \begin{tabular}{l|l|l|} 
OK \\
\end{tabular} & 0,998769 \\
\hline 92 & 2,86 & 0,84 & 1,56 & 0,94 & 1,12 & 1,11 & $-0,12$ & 2,31 & 1,09 & 1,25 & 1 & 1 OK & 0,693863 \\
\hline 93 & 0,58 & 1,04 & $-0,05$ & 2,53 & 0,89 & 1,02 & $-0,09$ & 1,33 & 1,37 & 1,22 & 1 & 1 OK & 0,984634 \\
\hline 94 & 0,86 & 1,05 & 1,10 & 1,09 & 0,49 & 1,06 & $-0,19$ & 1,86 & 1,48 & 1,27 & 1 & \begin{tabular}{l|l|}
1 & $O K$ \\
\end{tabular} & 0,501676 \\
\hline 95 & 2,42 & 0,63 & 1,04 & 1,21 & 1,65 & 1,18 & $-0,03$ & 2,68 & 0,91 & 1,18 & 1 & \begin{tabular}{l|l|}
1 & $O K$ \\
\end{tabular} & 0,980148 \\
\hline 96 & 11,63 & 0,89 & 1,28 & 0,79 & 1,28 & 1,68 & $-0,05$ & 2,52 & 1,07 & 1,20 & 1 & 1 OK & \\
\hline 97 & 1,26 & 1,01 & 0,92 & 0,95 & 0,85 & 1,04 & $-0,11$ & 2,61 & 0,42 & 1,33 & 1 & 1 |OK & 0,903859 \\
\hline 98 & 0,69 & 0,89 & 1,07 & 1,03 & 1,01 & 1,07 & $-0,82$ & 2,87 & 1,79 & 1,06 & 0 & \begin{tabular}{l|l|l|}
0 & $\mathrm{OK}$ \\
\end{tabular} & 0,027636 \\
\hline 99 & 1,25 & 0,74 & 2,16 & 0,96 & 0,91 & 0,94 & $-0,90$ & 3,39 & 0,62 & 0,99 & 0 & \begin{tabular}{l|l|}
0 & $O K$ \\
\end{tabular} & 0 \\
\hline 100 & 1,00 & 1,07 & 0,84 & 1,05 & 0,96 & 0,86 & $-0,52$ & 0,19 & 0,77 & 1,10 & 0 & \begin{tabular}{l|l|l}
0 & $O K$ \\
\end{tabular} & 0,025891 \\
\hline 101 & 0,55 & 0,89 & 2,30 & 0,90 & 0,78 & 0,89 & $-0,46$ & 0,33 & 1,16 & 1,28 & 0 & \begin{tabular}{l|l|}
0 & OK \\
\end{tabular} & 0,000567 \\
\hline 102 & 2,28 & 0,90 & 1,41 & 0,96 & 2,81 & 1,04 & $-0,13$ & 2,40 & 1,28 & 0,60 & 0 & \begin{tabular}{l|l|}
1 & Wrong \\
\end{tabular} & 0,990337 \\
\hline 103 & 1,14 & 1,32 & $-1,48$ & 1,21 & 1,46 & 1,36 & $-0,54$ & 1,28 & 0,48 & 1,14 & 0 & 0 OK & 0 \\
\hline 104 & 1,22 & 1,41 & 1,14 & 0,88 & 1,01 & 0,92 & $-0,26$ & 0,90 & 0,79 & 0,98 & 0 & 0 OK & 0,078487 \\
\hline 105 & 1,84 & 1,11 & 1,13 & 1,00 & 1,09 & 1,00 & $-0,18$ & 0,01 & 0,71 & 1,24 & 0 & \begin{tabular}{l|l|}
1 & Wrong \\
\end{tabular} & 0,580496 \\
\hline 106 & 0,48 & 0,90 & 0,87 & 1,44 & 0,74 & 0,84 & $-0,04$ & 1,01 & 0,94 & 1,98 & 0 & \begin{tabular}{l|l|l|}
0 & $\mathrm{OK}$ \\
\end{tabular} & 0,220983 \\
\hline 107 & 1,42 & 1,52 & 1,05 & 0,95 & 1,01 & 1,07 & $-0,34$ & 0,87 & 0,73 & 1,02 & 0 & 0 OK & 0,172711 \\
\hline 108 & 0,77 & 1,04 & 1,69 & 0,95 & 1,07 & 1,10 & $-0,85$ & 0,89 & 2,35 & 1,11 & 0 & \begin{tabular}{l|l|l}
0 & OK \\
\end{tabular} & \\
\hline 109 & 0,96 & 1,09 & 0,74 & 1,08 & 1,09 & 0,92 & $-0,09$ & 1,33 & 1,79 & 1,25 & 0 & 0 OK & 0,105083 \\
\hline 110 & 0,95 & 1,33 & 0,96 & 0,83 & 1,61 & 0,72 & $-0,03$ & 0,82 & 0,71 & 1,01 & 0 & \begin{tabular}{l|l|l}
0 & $O K$ \\
\end{tabular} & 0,017311 \\
\hline 111 & 1,10 & 0,98 & 1,40 & 0,91 & 0,89 & 1,14 & $-0,21$ & 1,07 & 1,14 & 1,33 & 0 & 0 OK & 0,00011 \\
\hline 112 & 1,30 & 0,61 & 1,25 & 0,96 & 0,88 & 0,95 & $-0,32$ & 0,87 & 0,93 & 1,13 & 0 & \begin{tabular}{l|l|}
0 & $O K$ \\
\end{tabular} & 0,006461 \\
\hline 113 & 1,26 & 0,90 & 0,86 & 1,04 & 1,61 & 0,84 & $-0,49$ & 0,31 & 1,06 & 0,90 & 0 & \begin{tabular}{l|l|l|}
0 & $\mathrm{OK}$ \\
\end{tabular} & 0,005441 \\
\hline 114 & 0,61 & 0,92 & 1,00 & 0,94 & 1,21 & 0,48 & $-0,90$ & 0,00 & 1,06 & 1,03 & 0 & \begin{tabular}{l|l|}
0 & $O K$ \\
\end{tabular} & 0,005767 \\
\hline 115 & 0,90 & 0,99 & $-0,30$ & 1,16 & 1,03 & 0,96 & $-1,08$ & 0,63 & 1,24 & 1,04 & 0 & \begin{tabular}{l|l|l|}
$0 K$ \\
\end{tabular} & \\
\hline 116 & 1,19 & 0,41 & $-0,73$ & 0,93 & 1,08 & 0,98 & $-0,25$ & 1,09 & 1,13 & 1,39 & 0 & \begin{tabular}{l|l|}
0 & $O K$ \\
\end{tabular} & 0,102564 \\
\hline 117 & 1,26 & 1,32 & $-4,13$ & 0,70 & 0,92 & 0,85 & $-0,19$ & 0,86 & 0,82 & 1,22 & 0 & \begin{tabular}{l|l|l}
0 & $O K$ \\
\end{tabular} & 0,000151 \\
\hline 118 & 1,10 & 1,08 & 1,28 & 1,11 & 0,70 & 0,85 & $-0,21$ & 2,32 & 0,88 & 1,08 & 0 & 0 OK & 0,39021 \\
\hline 119 & 1,26 & 1,54 & 1,15 & 0,87 & 1,34 & 0,87 & $-0,46$ & 3,22 & 1,36 & 0,75 & 0 & 0 OK & 0,004764 \\
\hline 120 & 1,13 & 1,22 & 0,87 & 1,01 & 1,07 & 0,81 & $-0,07$ & 0,71 & 1,72 & 0,98 & 0 & \begin{tabular}{l|l|l}
0 & $O K$ \\
\end{tabular} & 0,070113 \\
\hline
\end{tabular}




\section{Uğurlu - Ş. Sevim 7/1 (2015) 60-89}

\begin{tabular}{|c|c|c|c|c|c|c|c|c|c|c|c|c|c|}
\hline 121 & 1,35 & 1,07 & 1,02 & 1,11 & 1,04 & 0,71 & $-0,09$ & 1,08 & 1,02 & 1,11 & 0 & \begin{tabular}{l|l}
0 & $\mathrm{OK}$ \\
\end{tabular} & 0,08997 \\
\hline 122 & 0,86 & 0,70 & 2,02 & 0,74 & 1,79 & 1,02 & $-0,14$ & 1,97 & 0,69 & 1,78 & 0 & \begin{tabular}{l|l|}
0 & $O K$ \\
\end{tabular} & 0,035467 \\
\hline 123 & 0,73 & 0,87 & 0,84 & 0,92 & 0,96 & 0,91 & $-0,06$ & 1,81 & 0,64 & 1,29 & 0 & \begin{tabular}{l|l|}
0 & $\mathrm{OK}$ \\
\end{tabular} & 0,37019 \\
\hline 124 & 0,88 & 1,00 & 1,05 & 0,94 & 1,10 & 1,44 & $-0,16$ & 3,05 & 1,44 & 1,30 & 0 & \begin{tabular}{l|l|}
1 & Wrong \\
\end{tabular} & 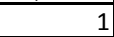 \\
\hline 125 & 0,95 & 0,98 & 1,23 & 0,96 & 0,89 & 0,95 & $-0,23$ & 0,32 & 1,71 & 1,20 & 0 & \begin{tabular}{l|l|}
0 & $\mathrm{OK}$ \\
\end{tabular} & 0,415216 \\
\hline 126 & 1,04 & 1,46 & 0,89 & 0,86 & 1,05 & 0,96 & $-0,02$ & 0,96 & 1,02 & 1,00 & 0 & \begin{tabular}{l|l}
0 & $\mathrm{OK}$ \\
\end{tabular} & 0,097735 \\
\hline 127 & 1,04 & 1,53 & 1,05 & 0,94 & 1,16 & 1,03 & $-0,13$ & 1,67 & 0,68 & 1,38 & 0 & \begin{tabular}{l|l|}
0 & $\mathrm{OK}$ \\
\end{tabular} & 0,091768 \\
\hline 128 & 0,62 & 2,72 & 0,95 & 1,27 & 0,75 & 1,11 & $-0,07$ & 0,70 & 1,14 & 1,55 & 0 & \begin{tabular}{l|l|l}
0 & $\mathrm{OK}$ \\
\end{tabular} & 0,00306 \\
\hline 129 & 0,78 & 1,33 & 0,80 & 1,66 & 0,42 & 0,92 & $-0,10$ & 2,42 & 2,72 & 1,55 & 0 & \begin{tabular}{l|l|l}
0 & $O K$ \\
\end{tabular} & 0,236867 \\
\hline 130 & 0,97 & 1,24 & 0,49 & 0,77 & 0,68 & 1,20 & $-0,06$ & 3,36 & 0,34 & 1,53 & 0 & \begin{tabular}{l|l|l}
0 & $O K$ \\
\end{tabular} & 0,00042 \\
\hline 131 & 1,28 & 0,46 & 3,74 & 0,64 & 0,83 & 0,81 & $-0,07$ & 7,33 & 0,36 & 1,31 & 0 & \begin{tabular}{l|l|l}
0 & $O K$ \\
\end{tabular} & 0,118642 \\
\hline 132 & 1,13 & 1,65 & 1,29 & 1,02 & 0,85 & 1,19 & $-0,03$ & 0,86 & 5,45 & 1,07 & 0 & \begin{tabular}{l|l|l}
0 & OK \\
\end{tabular} & 0,001267 \\
\hline 133 & 0,91 & 1,51 & 1,23 & 0,73 & 1,58 & 0,86 & $-0,02$ & 0,59 & 1,33 & 1,30 & 0 & \begin{tabular}{l|l|}
0 & $\mathrm{OK}$ \\
\end{tabular} & 0,044306 \\
\hline 134 & 0,95 & 1,24 & $-0,05$ & 0,78 & 1,07 & 0,86 & $-0,29$ & 0,66 & 1,15 & 1,47 & 0 & \begin{tabular}{l|l|l}
0 & $\mathrm{OK}$ \\
\end{tabular} & 0,002116 \\
\hline 135 & 0,78 & 0,56 & 0,54 & 0,31 & 0,68 & 0,93 & $-0,08$ & 99,39 & 0,71 & 1,37 & 0 & \begin{tabular}{l|l|}
0 & $\mathrm{OK}$ \\
\end{tabular} & 0,00281 \\
\hline 136 & 1,05 & 2,53 & 1,22 & 0,86 & 1,09 & 0,85 & $-0,22$ & 0,25 & 0,86 & 1,16 & 0 & \begin{tabular}{l|l|}
0 & $O K$ \\
\end{tabular} & 0,038689 \\
\hline 137 & 0,64 & 0,80 & 1,15 & 0,93 & 0,88 & 0,90 & $-0,18$ & 0,17 & 0,52 & 1,47 & 0 & \begin{tabular}{l|l|l}
0 & $O K$ \\
\end{tabular} & 0,087736 \\
\hline 138 & 1,14 & 1,22 & 0,75 & 1,17 & 0,82 & 1,23 & $-0,39$ & 0,94 & 0,72 & 1,32 & 0 & \begin{tabular}{l|l|}
0 & $O K$ \\
\end{tabular} & 0,075017 \\
\hline 139 & 4,04 & 0,99 & 0,99 & 1,00 & 1,22 & 0,97 & $-0,33$ & 0,79 & 0,87 & 0,74 & 0 & \begin{tabular}{l|l|l}
0 & $\mathrm{OK}$ \\
\end{tabular} & 0,134074 \\
\hline 140 & 9,29 & 0,58 & 1,11 & 0,93 & 1,89 & 0,56 & $-0,19$ & 1,07 & 0,73 & 1,16 & 0 & \begin{tabular}{l|l|}
0 & $O K$ \\
\end{tabular} & 0,431537 \\
\hline 141 & 0,59 & 0,69 & $-0,08$ & 1,03 & 1,70 & 0,88 & $-0,70$ & 0,72 & 1,94 & 1,01 & 0 & \begin{tabular}{l|l|}
0 & $O K$ \\
\end{tabular} & 0,0301 \\
\hline 142 & 1,06 & 0,51 & 1,96 & 0,88 & 0,98 & 1,04 & $-0,22$ & 1,13 & 0,75 & 1,41 & 0 & \begin{tabular}{l|l|}
0 & $\mathrm{OK}$ \\
\end{tabular} & 0,002355 \\
\hline 143 & 0,73 & 0,84 & 0,38 & 0,99 & 1,07 & 0,87 & $-0,66$ & 0,32 & 1,13 & 0,95 & 0 & \begin{tabular}{l|l|l}
0 & $O K$ \\
\end{tabular} & 0,01239 \\
\hline 144 & 0,69 & 1,29 & 1,07 & 0,88 & 1,18 & 0,87 & $-0,36$ & 1,28 & 0,83 & 1,27 & 0 & \begin{tabular}{l|l|}
0 & $\mathrm{OK}$ \\
\end{tabular} & 0,018594 \\
\hline 145 & 0,93 & 1,30 & $-1,66$ & 0,73 & 1,06 & 0,93 & $-0,44$ & 0,40 & 1,53 & 1,02 & 0 & \begin{tabular}{l|l}
0 & $\mathrm{OK}$ \\
\end{tabular} & 0,0327 \\
\hline 146 & 3,22 & 1,03 & $-0,45$ & 0,94 & 0,58 & 0,60 & $-0,15$ & 4,47 & 0,83 & 1,42 & 0 & \begin{tabular}{l|l|}
0 & $O K$ \\
\end{tabular} & 0,01536 \\
\hline 147 & 0,33 & $-3,12$ & $-0,17$ & 0,66 & 0,50 & 0,75 & $-0,13$ & 0,05 & 0,90 & 2,96 & 0 & \begin{tabular}{l|l|}
1 & Wrong \\
\end{tabular} & 0,999821 \\
\hline 148 & 0,93 & 0,90 & 1,17 & 0,81 & 0,70 & 1,00 & $-0,25$ & 2,37 & 1,08 & 1,16 & 0 & \begin{tabular}{l|l|}
0 & $\mathrm{OK}$ \\
\end{tabular} & 0,194004 \\
\hline 149 & 0,71 & 1,89 & 1,21 & 0,64 & 1,23 & 1,00 & $-0,03$ & 2,95 & 5,01 & 1,10 & 0 & \begin{tabular}{l|l|l}
0 & $\mathrm{OK}$ \\
\end{tabular} & 0,093648 \\
\hline 150 & 2,08 & $-0,39$ & $-2,72$ & 0,62 & 0,39 & 0,38 & $-0,06$ & 35,52 & 0,45 & 5,43 & 0 & \begin{tabular}{l|l|}
0 & $\mathrm{OK}$ \\
\end{tabular} & 0,002357 \\
\hline 151 & 1,17 & 1,42 & 0,96 & 1,05 & 1,10 & 1,05 & $-0,31$ & 1,06 & 0,66 & 1,25 & 0 & \begin{tabular}{l|l|l}
0 & OK \\
\end{tabular} & 0,074084 \\
\hline 152 & 1,57 & 0,93 & 1,05 & 1,00 & 0,86 & 0,96 & $-0,62$ & 0,73 & 1,00 & 0,94 & 0 & \begin{tabular}{l|l|l}
0 & $\mathrm{OK}$ \\
\end{tabular} & 0,19505 \\
\hline 153 & 1,00 & 1,31 & 1,02 & 0,93 & 0,73 & 0,77 & $-0,42$ & 0,24 & 0,60 & 1,03 & 0 & \begin{tabular}{l|l|}
0 & $\mathrm{OK}$ \\
\end{tabular} & 0,059432 \\
\hline 154 & 0,84 & 0,97 & 0,70 & 2,00 & 0,86 & 0,85 & $-0,14$ & 0,44 & 1,60 & 1,05 & 0 & \begin{tabular}{l|l|}
0 & $\mathrm{OK}$ \\
\end{tabular} & 0,126751 \\
\hline 155 & 0,68 & 1,09 & 0,78 & 0,95 & 0,99 & 0,50 & $-0,23$ & 0,62 & 1,08 & 0,88 & 0 & \begin{tabular}{l|l|}
0 & $O K$ \\
\end{tabular} & 0,023884 \\
\hline 156 & 1,01 & 1,00 & 1,28 & 0,87 & 1,13 & 0,95 & $-0,13$ & 0,92 & 1,10 & 1,18 & 0 & \begin{tabular}{l|l|}
1 & Wrong \\
\end{tabular} & 0,639999 \\
\hline 157 & 0,80 & 0,97 & 0,87 & 0,97 & 1,05 & 0,71 & $-0,25$ & 0,43 & 1,31 & 1,05 & 0 & \begin{tabular}{l|l|}
0 & $\mathrm{OK}$ \\
\end{tabular} & 0,032416 \\
\hline 158 & 1,13 & 1,41 & 0,95 & 1,13 & 0,81 & 1,79 & $-0,30$ & 0,55 & 0,88 & 1,26 & 0 & \begin{tabular}{l|l|}
0 & $O K$ \\
\end{tabular} & 0 \\
\hline 159 & 0,66 & 0,95 & 0,26 & 1,48 & 1,64 & 1,19 & $-0,15$ & 0,19 & 1,18 & 1,08 & 0 & \begin{tabular}{l|l|}
1 & Wrong \\
\end{tabular} & \\
\hline 160 & 0,96 & 0,85 & 0,85 & 0,67 & 1,18 & 0,91 & $-0,11$ & 1,91 & 0,45 & 0,95 & 0 & \begin{tabular}{l|l|}
0 & $O K$ \\
\end{tabular} & 0,179898 \\
\hline 161 & 0,65 & 1,19 & 1,20 & 0,87 & 1,29 & 0,74 & $-0,50$ & 0,45 & 0,98 & 1,13 & 0 & \begin{tabular}{l|l|}
0 & $\mathrm{OK}$ \\
\end{tabular} & 0,018807 \\
\hline 162 & 0,72 & 0,87 & 1,21 & 0,93 & 0,94 & 0,74 & $-0,08$ & 0,80 & 0,95 & 1,60 & 0 & \begin{tabular}{l|l|}
0 & $\mathrm{OK}$ \\
\end{tabular} & 0,360089 \\
\hline 163 & 0,80 & 1,06 & 0,80 & 1,14 & 1,09 & 0,90 & $-0,18$ & 1,08 & 0,76 & 1,37 & 0 & \begin{tabular}{l|l|}
0 & $O K$ \\
\end{tabular} & 0,053863 \\
\hline 164 & 0,51 & 1,54 & $-0,41$ & 1,76 & 0,66 & 0,66 & $-0,03$ & 1,59 & 0,62 & 1,22 & 0 & \begin{tabular}{l|l|}
0 & $\mathrm{OK}$ \\
\end{tabular} & 0,01237 \\
\hline 165 & 0,42 & 0,88 & 0,53 & 1,01 & 0,68 & 0,43 & $-0,06$ & 4,07 & 1,57 & 1,09 & 0 & \begin{tabular}{l|l|}
0 & $\mathrm{OK}$ \\
\end{tabular} & 0,025588 \\
\hline 166 & 1,29 & 2,46 & 1,09 & 0,97 & 1,38 & 0,96 & 0,00 & 3,15 & 0,76 & 1,59 & 0 & \begin{tabular}{l|l|}
0 & $\mathrm{OK}$ \\
\end{tabular} & 0,034679 \\
\hline 167 & 0,52 & 0,36 & 0,51 & 0,06 & 1,08 & 0,78 & $-0,28$ & 0,75 & 0,03 & 2,64 & 0 & \begin{tabular}{l|l|}
0 & $\mathrm{OK}$ \\
\end{tabular} & 0,000249 \\
\hline 168 & 0,88 & 1,14 & 1,44 & 0,85 & 0,78 & 0,42 & $-0,76$ & 0,75 & 0,54 & 0,90 & 0 & \begin{tabular}{l|l|}
0 & $\mathrm{OK}$ \\
\end{tabular} & 0,020935 \\
\hline 169 & 0,94 & 0,79 & 1,20 & 0,97 & 0,77 & 1,09 & $-0,12$ & 4,35 & 1,31 & 1,83 & 0 & \begin{tabular}{l|l|}
0 & $\mathrm{OK}$ \\
\end{tabular} & 0,062422 \\
\hline 170 & 0,92 & 0,98 & 1,10 & 0,99 & 1,03 & 0,92 & $-0,76$ & 1,01 & 0,85 & 1,05 & 0 & \begin{tabular}{l|l|}
0 & $\mathrm{OK}$ \\
\end{tabular} & 0,032142 \\
\hline 171 & 0,68 & 1,20 & 0,85 & 1,02 & 0,98 & 0,79 & $\begin{array}{r}-0,33 \\
\end{array}$ & 0,35 & 0,66 & 1,12 & 0 & \begin{tabular}{l|l|}
0 & $\mathrm{OK}$ \\
\end{tabular} & 0,025209 \\
\hline 172 & 0,84 & 1,01 & 0,02 & 1,12 & 1,01 & 0,89 & $-0,40$ & 0,81 & 0,66 & 1,22 & 0 & \begin{tabular}{l|l|}
0 & $\mathrm{OK}$ \\
\end{tabular} & 0,004815 \\
\hline 173 & 0,91 & 0,98 & $-1,29$ & 1,00 & 0,99 & 0,60 & $-0,22$ & 3,83 & 0,71 & 1,18 & 0 & \begin{tabular}{l|l|}
0 & $\mathrm{OK}$ \\
\end{tabular} & 0,001681 \\
\hline 174 & 0,98 & 2,30 & 1,17 & 0,85 & 1,01 & 1,00 & $-0,17$ & 1,06 & 0,21 & 1,32 & 0 & \begin{tabular}{l|l|}
0 & $\mathrm{OK}$ \\
\end{tabular} & 0,114382 \\
\hline 175 & 0,88 & 1,32 & 0,86 & 1,48 & 0,77 & 1,07 & $-0,24$ & 0,88 & 0,57 & 1,35 & 0 & \begin{tabular}{l|l|}
0 & $O K$ \\
\end{tabular} & 0,16187 \\
\hline 176 & 1,04 & 1,20 & 1,07 & 0,87 & 0,80 & 0,81 & $-0,34$ & 1,07 & 0,74 & 1,09 & 0 & \begin{tabular}{l|l|}
0 & $\mathrm{OK}$ \\
\end{tabular} & 0,085602 \\
\hline 177 & 0,97 & 0,92 & 1,03 & 0,95 & 1,13 & 0,78 & $-0,16$ & 1,29 & 0,75 & 1,31 & 0 & \begin{tabular}{l|l|}
0 & OK \\
\end{tabular} & 0,088214 \\
\hline 178 & 1,43 & 0,52 & 0,70 & 0,89 & 0,96 & 1,00 & $-0,47$ & 6,92 & 1,05 & 1,24 & 0 & \begin{tabular}{l|l|}
0 & $O K$ \\
\end{tabular} & 0,040513 \\
\hline 179 & 1,48 & 0,87 & $-0,02$ & 0,94 & 0,85 & 0,84 & $-0,56$ & 1,82 & 0,54 & 1,23 & 0 & \begin{tabular}{l|l|}
0 & $O K$ \\
\end{tabular} & 0,007456 \\
\hline 180 & 0,88 & 0,86 & 0,84 & 1,34 & 0,93 & 0,86 & $-0,03$ & 1,15 & 0,93 & 1,22 & 0 & \begin{tabular}{l|l|}
0 & $O K$ \\
\end{tabular} & 0,379664 \\
\hline 181 & 0,89 & 1,26 & 0,30 & 0,96 & 1,05 & 0,97 & $-1,41$ & 1,02 & 1,02 & 1,12 & 0 & \begin{tabular}{l|l|}
0 & $O K$ \\
\end{tabular} & \\
\hline
\end{tabular}




\section{Uğurlu - Ş. Sevim 7/1 (2015) 60-89}

\begin{tabular}{|c|c|c|c|c|c|c|c|c|c|c|c|c|c|}
\hline 182 & 1,08 & 1,46 & 0,84 & 0,95 & 0,61 & 0,76 & $-0,76$ & 0,92 & 0,50 & 2,03 & 0 & \begin{tabular}{l|l}
0 & $\mathrm{OK}$ \\
\end{tabular} & 0,030961 \\
\hline 183 & 0,90 & 1,44 & 0,50 & 1,17 & 0,74 & 1,24 & $-0,31$ & 0,86 & 1,10 & 1,62 & 0 & \begin{tabular}{l|l|l}
0 & $O K$ \\
\end{tabular} & 0,022536 \\
\hline 184 & 1,20 & 1,25 & 1,24 & 0,95 & 0,91 & 1,00 & $-0,45$ & 1,99 & 0,88 & 1,17 & 0 & \begin{tabular}{l|l|}
0 & $\mathrm{OK}$ \\
\end{tabular} & 0,310985 \\
\hline 185 & 0,82 & 1,69 & 1,02 & 0,93 & 0,81 & 0,29 & $-0,18$ & 3,49 & 0,82 & 1,19 & 0 & \begin{tabular}{l|l|l}
0 & $\mathrm{OK}$ \\
\end{tabular} & 0,052092 \\
\hline 186 & 0,93 & 1,05 & 0,80 & 1,11 & 1,00 & 1,01 & $-0,15$ & 0,35 & 0,83 & 1,18 & 0 & \begin{tabular}{l|l|}
0 & $\mathrm{OK}$ \\
\end{tabular} & 0,365092 \\
\hline 187 & 1,08 & 1,15 & 1,35 & 0,89 & 0,76 & 0,95 & $-0,56$ & 1,44 & 0,75 & 1,13 & 0 & \begin{tabular}{l|l}
0 & $\mathrm{OK}$ \\
\end{tabular} & 0,426641 \\
\hline 188 & 0,84 & 0,93 & 1,00 & 0,98 & 1,00 & 1,03 & $-0,01$ & 1,03 & 1,48 & 1,01 & 0 & \begin{tabular}{l|l|}
1 & Wrong \\
\end{tabular} & 0,988625 \\
\hline 189 & 1,45 & 1,08 & 0,90 & 1,12 & 0,64 & 1,60 & $-0,06$ & 0,74 & 0,56 & 1,58 & 0 & \begin{tabular}{l|l|}
0 & $O K$ \\
\end{tabular} & \\
\hline 190 & 0,78 & 1,16 & 0,59 & 1,16 & 1,22 & 0,96 & $-0,34$ & 2,38 & 0,91 & 0,95 & 0 & \begin{tabular}{l|l|l}
0 & $O K$ \\
\end{tabular} & 0,013303 \\
\hline 191 & 0,20 & 1,20 & 0,30 & 0,76 & 1,00 & 0,75 & $-0,24$ & 0,70 & 0,27 & 1,42 & 0 & \begin{tabular}{l|l|l}
0 & $O K$ \\
\end{tabular} & 0,006338 \\
\hline 192 & 1,26 & 1,24 & 1,14 & 0,01 & 1,03 & 1,03 & 0,00 & 0,58 & 0,59 & 1,28 & 0 & \begin{tabular}{l|l}
1 & Wrong \\
\end{tabular} & 0,968693 \\
\hline 193 & 1,06 & 0,79 & 1,11 & 0,80 & 1,12 & 0,69 & $-0,07$ & 14,23 & 2,35 & 1,11 & 0 & \begin{tabular}{l|l|l}
0 & OK \\
\end{tabular} & 0,168213 \\
\hline 194 & 0,95 & 0,76 & 0,75 & 1,04 & 0,76 & 1,07 & $-0,19$ & 0,28 & 0,89 & 1,31 & 0 & \begin{tabular}{l|l|}
0 & $\mathrm{OK}$ \\
\end{tabular} & 0,008985 \\
\hline 195 & 0,55 & 1,86 & 4,05 & 0,50 & 0,95 & 2,08 & $-0,07$ & 0,30 & 0,75 & 2,30 & 0 & \begin{tabular}{l|l|}
0 & $\mathrm{OK}$ \\
\end{tabular} & \\
\hline 196 & 1,04 & 0,62 & $-1,67$ & 1,45 & 1,00 & 0,61 & $-0,86$ & 1,16 & 1,15 & 1,33 & 0 & \begin{tabular}{l|l|}
0 & $\mathrm{OK}$ \\
\end{tabular} & 0,000696 \\
\hline 197 & 1,12 & 1,26 & 1,15 & $\begin{array}{ll}0,97 \\
\end{array}$ & 1,44 & 0,88 & $-0,87$ & 0,36 & 1,02 & 0,98 & 0 & \begin{tabular}{l|l|}
0 & $O K$ \\
\end{tabular} & 0,004067 \\
\hline 198 & 1,77 & 0,46 & 1,48 & 0,89 & 0,87 & 1,00 & $-0,53$ & 1,80 & 1,17 & 1,05 & 0 & \begin{tabular}{l|l|l}
0 & $O K$ \\
\end{tabular} & 0,002953 \\
\hline 199 & 1,19 & 0,68 & 2,46 & 1,05 & 1,72 & 1,09 & $-0,38$ & 5,06 & 0,95 & 1,21 & 0 & \begin{tabular}{l|l|}
0 & $O K$ \\
\end{tabular} & 0,001687 \\
\hline 200 & 1,76 & 0,59 & 1,57 & 1,09 & 1,63 & 1,16 & $-0,14$ & 1,14 & 1,24 & 1,09 & 0 & \begin{tabular}{l|l|l}
0 & $\mathrm{OK}$ \\
\end{tabular} & 0,39487 \\
\hline 201 & 0,94 & $-0,16$ & 6,72 & 0,93 & 2,51 & 0,98 & $-0,70$ & 0,82 & 0,70 & 1,42 & 0 & \begin{tabular}{l|l|}
0 & $O K$ \\
\end{tabular} & 0,000095 \\
\hline 202 & 0,85 & 0,83 & 2,44 & 0,84 & 0,72 & 0,92 & $-0,22$ & 2,00 & 1,51 & 1,13 & 0 & \begin{tabular}{l|l|}
0 & $O K$ \\
\end{tabular} & 0,012378 \\
\hline 203 & 0,53 & 0,75 & 2,14 & 1,06 & 1,02 & 0,68 & $-0,18$ & 17,56 & 1,39 & 1,50 & 0 & \begin{tabular}{l|l|}
0 & $\mathrm{OK}$ \\
\end{tabular} & 0,000225 \\
\hline 204 & 1,11 & 0,89 & 1,30 & 0,85 & 0,99 & 1,25 & $-0,04$ & 0,98 & 1,44 & 1,72 & 0 & \begin{tabular}{l|l|l}
0 & $O K$ \\
\end{tabular} & 0,068417 \\
\hline 205 & 0,86 & 0,13 & 1,11 & 0,89 & 0,78 & 1,08 & $-0,40$ & 2,19 & 0,65 & 1,43 & 0 & \begin{tabular}{l|l|}
0 & $\mathrm{OK}$ \\
\end{tabular} & 0,009814 \\
\hline 206 & 1,61 & 0,57 & $-0,57$ & 0,92 & 1,04 & 1,67 & $-0,85$ & 1,00 & 0,39 & 1,51 & 0 & \begin{tabular}{l|l|l}
0 & $O K$ \\
\end{tabular} & \\
\hline 207 & 1,56 & 0,14 & 1,15 & 0,96 & 1,00 & 0,78 & $-0,06$ & 1,22 & 0,77 & 1,26 & 0 & \begin{tabular}{l|l|l}
0 & $O K$ \\
\end{tabular} & 0,028603 \\
\hline 208 & 0,90 & 0,84 & 1,09 & 0,82 & 0,99 & 1,11 & $-0,02$ & 1,07 & 0,64 & 1,57 & 0 & \begin{tabular}{l|l|l}
0 & OK \\
\end{tabular} & 0,006965 \\
\hline 209 & 1,29 & 0,92 & 0,98 & 1,00 & 1,01 & 1,10 & $-0,23$ & 0,79 & 0,72 & 1,30 & 0 & \begin{tabular}{l|l|}
0 & $\mathrm{OK}$ \\
\end{tabular} & 0,240514 \\
\hline 210 & 0,87 & $-1,42$ & 7,10 & 0,88 & 0,71 & 0,87 & $-1,26$ & 1,14 & 1,05 & 1,46 & 0 & \begin{tabular}{l|l|l}
0 & $\mathrm{OK}$ \\
\end{tabular} & \\
\hline 211 & 1,16 & $-1,28$ & 1,51 & 0,93 & 0,18 & 1,09 & $-0,41$ & 1,01 & 0,82 & 1,38 & 0 & \begin{tabular}{l|l|}
0 & $\mathrm{OK}$ \\
\end{tabular} & 0,00025 \\
\hline 212 & 0,77 & 0,31 & 1,92 & 0,91 & 0,75 & 0,73 & $-0,51$ & 3,34 & 0,56 & 1,80 & 0 & \begin{tabular}{l|l|}
0 & $\mathrm{OK}$ \\
\end{tabular} & 0,000029 \\
\hline 213 & 1,19 & 0,42 & 2,89 & 0,99 & 0,82 & 0,98 & $-1,27$ & 2,00 & 0,56 & 1,42 & 0 & \begin{tabular}{l|l|}
0 & $\mathrm{OK}$ \\
\end{tabular} & 0 \\
\hline 214 & 1,36 & 1,06 & 0,55 & 0,91 & 0,72 & 1,12 & $-0,27$ & 0,28 & 1,09 & 1,70 & 0 & \begin{tabular}{l|l|}
0 & $\mathrm{OK}$ \\
\end{tabular} & 0,029059 \\
\hline 215 & 1,23 & 0,70 & 1,06 & 1,01 & 1,49 & 0,90 & $-0,14$ & 1,03 & 1,42 & 1,28 & 0 & \begin{tabular}{l|l|}
0 & $\mathrm{OK}$ \\
\end{tabular} & 0,400972 \\
\hline 216 & 1,75 & 0,99 & 1,30 & 1,05 & 0,81 & 1,69 & $-0,27$ & 3,00 & 1,69 & 0,89 & 0 & \begin{tabular}{l|l|}
0 & $O K$ \\
\end{tabular} & \\
\hline 217 & 0,95 & 1,02 & 1,53 & 1,06 & 1,22 & 1,11 & $-0,36$ & 0,40 & 1,21 & 1,54 & 0 & \begin{tabular}{l|l|}
0 & $O K$ \\
\end{tabular} & 0,404687 \\
\hline 218 & 1,23 & 1,01 & 1,09 & 0,79 & 1,25 & 0,79 & $-0,05$ & 0,26 & 0,87 & 1,06 & 0 & \begin{tabular}{l|l|}
0 & $\mathrm{OK}$ \\
\end{tabular} & 0,180072 \\
\hline 219 & 1,27 & 0,84 & 0,98 & 0,94 & 1,02 & 0,81 & $-0,11$ & 1,55 & 0,56 & 1,56 & 0 & \begin{tabular}{l|l|}
0 & $O K$ \\
\end{tabular} & 0,20708 \\
\hline 220 & 2,47 & 0,81 & 1,36 & 0,81 & 0,69 & 1,30 & $-0,05$ & 0,97 & 0,99 & 1,34 & 0 & \begin{tabular}{l|l|}
0 & $\mathrm{OK}$ \\
\end{tabular} & 0,098021 \\
\hline 221 & 1,05 & 0,79 & 1,40 & 0,81 & 0,72 & 1,09 & $-0,15$ & 1,06 & 0,49 & 1,66 & 0 & \begin{tabular}{l|l|}
0 & $O K$ \\
\end{tabular} & 0,010587 \\
\hline 222 & 0,83 & 1,06 & 0,93 & 0,95 & 0,57 & 0,78 & $-0,37$ & 3,51 & 0,37 & 1,50 & 0 & $\begin{array}{lll}0 & \mathrm{OK} \\
\end{array}$ & 0,1278 \\
\hline 223 & 1,22 & 0,82 & 2,04 & 0,52 & 0,99 & 0,76 & $-0,01$ & 0,32 & 4,06 & 1,35 & 0 & \begin{tabular}{l|l|}
0 & $\mathrm{OK}$ \\
\end{tabular} & 0,097489 \\
\hline 224 & 1,14 & 1,23 & 0,89 & 1,14 & 0,37 & 0,97 & $-0,13$ & 1,70 & 3,39 & 0,57 & 0 & \begin{tabular}{l|l|}
0 & $O K$ \\
\end{tabular} & 0,353619 \\
\hline 225 & 1,03 & 1,30 & 1,00 & 1,05 & 0,54 & 1,26 & $-0,08$ & 1,48 & 0,57 & 1,46 & 0 & 1 Wrong & 0,934464 \\
\hline 226 & 1,00 & 0,71 & 1,15 & 0,89 & 1,51 & 1,33 & $-0,12$ & 3,03 & 1,25 & 1,69 & 0 & \begin{tabular}{l|l|}
1 & Wrong \\
\end{tabular} & 0,998555 \\
\hline 227 & 1,07 & 0,04 & $-4,97$ & 0,73 & 0,94 & 1,45 & $-0,05$ & 0,28 & 2,93 & 1,35 & 0 & \begin{tabular}{l|l|}
0 & $\mathrm{OK}$ \\
\end{tabular} & 0,009043 \\
\hline 228 & 0,49 & 0,74 & $-0,06$ & 1,41 & 1,09 & 0,61 & $-0,04$ & 181,57 & 0,98 & 1,56 & 0 & \begin{tabular}{l|l|}
0 & $\mathrm{OK}$ \\
\end{tabular} & 0,036451 \\
\hline 229 & 0,72 & 0,13 & 1,11 & 0,58 & 3,19 & 0,56 & $-0,03$ & 0,68 & 1,13 & 1,24 & 0 & \begin{tabular}{l|l|l}
0 & $\mathrm{OK}$ \\
\end{tabular} & 0,149441 \\
\hline 230 & 0,73 & 0,56 & 1,00 & 0,57 & 1,06 & 1,14 & $-0,01$ & 1,16 & 0,57 & 2,07 & 0 & \begin{tabular}{l|l|}
0 & $\mathrm{OK}$ \\
\end{tabular} & 0,000308 \\
\hline 231 & 1,16 & 0,51 & 0,30 & 0,70 & 0,15 & 1,14 & $-0,24$ & 2,02 & 1,29 & 2,77 & 0 & \begin{tabular}{l|l|}
0 & $\mathrm{OK}$ \\
\end{tabular} & \\
\hline 232 & 0,98 & 0,90 & $-3,59$ & 0,87 & 1,46 & 0,99 & $-0,02$ & 0,11 & 0,82 & 1,59 & 0 & \begin{tabular}{l|l|}
0 & $\mathrm{OK}$ \\
\end{tabular} & 0,198852 \\
\hline 233 & 0,88 & 0,51 & 0,89 & 0,99 & 1,62 & 0,72 & $-0,19$ & 5,50 & 1,46 & 1,15 & 0 & \begin{tabular}{l|l|}
0 & $\mathrm{OK}$ \\
\end{tabular} & 0,091448 \\
\hline 234 & 1,23 & 1,47 & 2,20 & 0,81 & 0,82 & 1,72 & $-0,17$ & 0,46 & 1,24 & 1,31 & 0 & \begin{tabular}{l|l|}
0 & $O K$ \\
\end{tabular} & 0 \\
\hline 235 & 0,64 & 0,65 & 0,78 & $\begin{array}{ll}0,97 \\
\end{array}$ & 1,00 & 0,60 & $-0,49$ & 3,64 & 0,67 & 1,29 & 0 & \begin{tabular}{l|l|}
0 & $\mathrm{OK}$ \\
\end{tabular} & 0,019893 \\
\hline 236 & 0,39 & 0,79 & 1,17 & 0,97 & 0,97 & 1,15 & $-0,32$ & 1,27 & 4,03 & 0,83 & 0 & \begin{tabular}{l|l|}
0 & $O K$ \\
\end{tabular} & 0,000127 \\
\hline 237 & 0,48 & 1,09 & 1,16 & 1,07 & 1,22 & 1,52 & $-0,19$ & 1,25 & 1,44 & 1,05 & 0 & 1 Wrong & 0,99986 \\
\hline 238 & 0,84 & 0,25 & 0,40 & 0,99 & 0,77 & 0,97 & $-0,54$ & 4,13 & 0,67 & 1,02 & 0 & \begin{tabular}{l|l|}
0 & $\mathrm{OK}$ \\
\end{tabular} & 0,003737 \\
\hline 239 & 2,16 & 1,42 & $-0,82$ & 0,90 & 1,25 & 1,21 & $-0,21$ & 0,30 & 1,16 & 1,11 & 0 & \begin{tabular}{l|l|}
1 & Wrong \\
\end{tabular} & 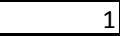 \\
\hline 240 & 1,22 & 1,18 & $-4,62$ & 0,84 & 0,91 & 1,16 & $-0,53$ & 4,93 & 0,96 & 1,44 & 0 & \begin{tabular}{l|l|l}
0 & $O K$ \\
\end{tabular} & 0 \\
\hline 241 & 1,13 & 0,43 & 1,25 & 1,02 & 1,45 & 0,96 & $-0,28$ & 0,91 & 1,95 & 1,18 & 0 & \begin{tabular}{l|l|}
0 & $O K$ \\
\end{tabular} & 0,104809 \\
\hline 242 & 1,15 & 0,22 & 0,41 & 0,84 & 0,72 & 1,13 & $-0,33$ & 1,58 & 0,92 & 1,17 & 0 & \begin{tabular}{l|l|l}
0 & $O K$ \\
\end{tabular} & 0,001885 \\
\hline
\end{tabular}


M. Uğurlu - Ş. Sevim 7/1 (2015) 60-89

\begin{tabular}{|c|c|c|c|c|c|c|c|c|c|c|c|c|c|}
\hline 243 & 0,96 & 0,73 & $-4,51$ & 1,75 & 1,79 & 1,55 & $-0,18$ & 1,09 & 2,39 & 1,29 & 0 & \begin{tabular}{l|l|}
0 & $\mathrm{OK}$ \\
\end{tabular} & 0 \\
\hline 244 & 1,24 & 0,97 & 1,54 & 0,60 & 2,03 & 0,87 & $-0,20$ & 0,38 & 0,88 & 1,08 & 0 & \begin{tabular}{l|l|}
0 & $\mathrm{OK}$ \\
\end{tabular} & 0,097315 \\
\hline 245 & 0,60 & 0,73 & 0,97 & 0,44 & 1,07 & 0,99 & $-0,02$ & 0,60 & 0,23 & 2,35 & 0 & \begin{tabular}{l|l}
0 & $\mathrm{OK}$ \\
\end{tabular} & 0,292214 \\
\hline 246 & 1,06 & 0,11 & 0,69 & 0,99 & 0,78 & 0,98 & $-1,33$ & 1,40 & 0,67 & 1,21 & 0 & \begin{tabular}{l|l|}
0 & $\mathrm{OK}$ \\
\end{tabular} & 0 \\
\hline 247 & 0,87 & 0,86 & 1,04 & 1,01 & 0,62 & 1,07 & $-0,37$ & 0,73 & 0,79 & 1,51 & 0 & \begin{tabular}{l|l|}
0 & $\mathrm{OK}$ \\
\end{tabular} & 0,035904 \\
\hline 248 & 1,16 & 0,65 & 1,14 & 1,01 & 0,67 & 0,95 & $-0,71$ & 0,93 & 0,92 & 1,25 & 0 & \begin{tabular}{l|l|}
0 & $\mathrm{OK}$ \\
\end{tabular} & 0,000996 \\
\hline 249 & 0,74 & 0,74 & 1,09 & 0,90 & 1,05 & 0,94 & $-0,34$ & 3,71 & 1,40 & 1,18 & 0 & \begin{tabular}{l|l|}
0 & $\mathrm{OK}$ \\
\end{tabular} & 0,083983 \\
\hline 250 & 0,86 & 1,34 & $-0,07$ & 1,10 & 1,05 & 1,34 & $-0,53$ & 1,27 & 1,38 & 1,18 & 0 & \begin{tabular}{l|l|}
0 & $\mathrm{OK}$ \\
\end{tabular} & 0 \\
\hline 251 & 1,00 & 0,57 & 1,09 & 0,94 & 0,96 & 1,06 & $-0,38$ & 3,45 & 0,51 & 1,18 & 0 & \begin{tabular}{l|l|}
0 & $\mathrm{OK}$ \\
\end{tabular} & 0,043771 \\
\hline 252 & 1,58 & 0,89 & 2,13 & 0,72 & 0,85 & 1,02 & $-0,17$ & 1,80 & 0,82 & 1,18 & 0 & \begin{tabular}{l|l|}
0 & $\mathrm{OK}$ \\
\end{tabular} & 0,027316 \\
\hline 253 & 1,00 & 0,93 & 0,59 & 1,11 & 0,94 & 0,83 & $-0,12$ & 0,41 & 0,90 & 1,04 & 0 & \begin{tabular}{l|l|}
0 & $\mathrm{OK}$ \\
\end{tabular} & 0,066812 \\
\hline 254 & 1,30 & 0,88 & 1,09 & 1,05 & 1,38 & 1,08 & $-0,22$ & 1,50 & 0,76 & 1,10 & 0 & \begin{tabular}{l|l|}
0 & $\mathrm{OK}$ \\
\end{tabular} & 0,309764 \\
\hline 255 & 0,87 & 0,45 & 0,92 & 0,96 & 1,37 & 0,35 & $-0,37$ & 1,72 & 1,35 & 0,98 & 0 & \begin{tabular}{l|l|}
0 & $\mathrm{OK}$ \\
\end{tabular} & 0,035007 \\
\hline 256 & 1,20 & 0,71 & 1,69 & 0,96 & 0,69 & 0,80 & $-0,14$ & 0,47 & 1,16 & 1,49 & 0 & \begin{tabular}{l|l|}
0 & $\mathrm{OK}$ \\
\end{tabular} & 0,008401 \\
\hline 257 & 1,47 & 0,92 & 0,82 & 0,99 & 1,02 & 1,17 & $-0,06$ & 1,04 & 1,57 & 1,10 & 0 & \begin{tabular}{l|l}
0 & $\mathrm{OK}$ \\
\end{tabular} & 0,056954 \\
\hline 258 & 1,37 & 0,76 & 0,19 & 0,85 & 1,01 & 1,08 & $-0,38$ & 1,84 & 1,05 & 1,36 & 0 & \begin{tabular}{l|l|}
0 & $\mathrm{OK}$ \\
\end{tabular} & 0,04981 \\
\hline 259 & 0,45 & 1,27 & 0,73 & 1,61 & 0,84 & 0,92 & $-0,09$ & 0,96 & 0,34 & 2,08 & 0 & \begin{tabular}{l|l}
0 & $\mathrm{OK}$ \\
\end{tabular} & 0,133124 \\
\hline 260 & 1,11 & 0,97 & 1,56 & 0,94 & 0,59 & 1,23 & $-0,21$ & 2,50 & 1,35 & 1,33 & 0 & \begin{tabular}{l|l|}
0 & $\mathrm{OK}$ \\
\end{tabular} & 0 \\
\hline 261 & 0,64 & 1,19 & 7,84 & 0,00 & 0,78 & 0,78 & $-0,05$ & 0,17 & 0,16 & 6,32 & 0 & \begin{tabular}{l|l|}
0 & $\mathrm{OK}$ \\
\end{tabular} & 0 \\
\hline 262 & 12,68 & 0,36 & 1,11 & 1,16 & 0,47 & 0,76 & 0,00 & 2,81 & 0,43 & 3,81 & 0 & \begin{tabular}{l|l|}
1 & Wrong \\
\end{tabular} & 1 \\
\hline 263 & 1,89 & 0,66 & 0,87 & 3,86 & 0,69 & 1,36 & $-0,01$ & 0,67 & 0,43 & 2,62 & 0 & \begin{tabular}{l|l|}
0 & $\mathrm{OK}$ \\
\end{tabular} & 0,013334 \\
\hline 264 & 3,88 & 0,37 & 0,50 & 0,85 & 0,90 & 0,90 & $-0,51$ & 0,35 & 0,34 & 1,43 & 0 & \begin{tabular}{l|l|}
0 & $\mathrm{OK}$ \\
\end{tabular} & 0,066465 \\
\hline 265 & 1,38 & 0,93 & 1,43 & 0,85 & 1,03 & 1,22 & $-0,18$ & 0,37 & 1,11 & 1,32 & 0 & \begin{tabular}{l|l|}
0 & $O K$ \\
\end{tabular} & 0,000094 \\
\hline 266 & 1,23 & 1,41 & 0,85 & 1,02 & 0,98 & 1,06 & $-0,75$ & 1,78 & 1,21 & 1,00 & 0 & \begin{tabular}{l|l|}
0 & $\mathrm{OK}$ \\
\end{tabular} & 0,472387 \\
\hline 267 & 1,02 & 1,22 & 1,10 & 1,04 & 0,97 & 1,22 & $-0,25$ & 2,34 & 1,47 & 1,15 & 0 & \begin{tabular}{l|l}
0 & $\mathrm{OK}$ \\
\end{tabular} & 0,061663 \\
\hline 268 & 1,64 & 0,86 & 5,32 & 1,03 & 0,77 & 1,53 & $-0,37$ & 1,80 & 1,38 & 1,02 & 0 & \begin{tabular}{l|l|}
0 & $\mathrm{OK}$ \\
\end{tabular} & 0,372869 \\
\hline 269 & 0,75 & 1,19 & $-0,39$ & 1,00 & 0,90 & 1,68 & $-0,19$ & 41,81 & 2,02 & 1,48 & 0 & \begin{tabular}{l|l}
0 & $\mathrm{OK}$ \\
\end{tabular} & 0 \\
\hline 270 & 0,98 & 0,66 & 7,96 & 0,67 & 0,68 & 0,94 & $-0,15$ & 1,84 & 0,72 & 1,53 & 0 & \begin{tabular}{l|l|}
0 & $\mathrm{OK}$ \\
\end{tabular} & 0,00001 \\
\hline 271 & 1,60 & 0,92 & 1,08 & 1,01 & 1,21 & 0,78 & $-0,46$ & 0,84 & 0,77 & 1,14 & 0 & \begin{tabular}{l|l}
0 & $\mathrm{OK}$ \\
\end{tabular} & 0,030071 \\
\hline 272 & 1,05 & 0,96 & 1,06 & 0,93 & 1,18 & 1,07 & $-0,27$ & 1,36 & 0,81 & 1,29 & 0 & \begin{tabular}{l|l|}
0 & $\mathrm{OK}$ \\
\end{tabular} & 0,476674 \\
\hline 273 & 1,19 & 1,04 & 6,15 & 0,83 & 0,66 & 0,94 & $-0,15$ & 0,93 & 0,90 & 1,90 & 0 & \begin{tabular}{l|l|}
0 & $\mathrm{OK}$ \\
\end{tabular} & 0 \\
\hline 274 & 1,03 & 0,80 & 0,89 & 0,90 & 0,51 & 0,89 & $-0,45$ & 3,61 & 0,65 & 1,42 & 0 & \begin{tabular}{l|l|}
0 & $\mathrm{OK}$ \\
\end{tabular} & 0,034099 \\
\hline 275 & 0,94 & 0,64 & 0,70 & 0,97 & 0,90 & 0,92 & $-0,55$ & 0,97 & 0,89 & 1,31 & 0 & \begin{tabular}{l|l}
0 & $\mathrm{OK}$ \\
\end{tabular} & 0,043054 \\
\hline 276 & 1,00 & 1,21 & 1,02 & 1,34 & 0,73 & 0,96 & $-0,03$ & 1,00 & 0,85 & 1,49 & 0 & \begin{tabular}{l|l}
1 & Wrong \\
\end{tabular} & 0,757384 \\
\hline 277 & 1,50 & 0,76 & 0,44 & 1,00 & 0,83 & 1,01 & $-1,36$ & 0,90 & 1,06 & 1,33 & 0 & \begin{tabular}{l|l|}
0 & $\mathrm{OK}$ \\
\end{tabular} & 0 \\
\hline 278 & 1,56 & 0,27 & 1,26 & 0,92 & 0,49 & 0,99 & $-0,53$ & 4,70 & 1,03 & 0,98 & 0 & \begin{tabular}{l|l}
0 & $\mathrm{OK}$ \\
\end{tabular} & 0,012033 \\
\hline 279 & 1,50 & 1,73 & $-1,43$ & 0,91 & 0,38 & 1,98 & $-0,37$ & 1,32 & 1,04 & 1,33 & 0 & \begin{tabular}{l|l|}
0 & $\mathrm{OK}$ \\
\end{tabular} & 0 \\
\hline 280 & 1,30 & 0,88 & 1,25 & 1,04 & 0,71 & 1,11 & $-0,47$ & 0,75 & 0,90 & 1,44 & 0 & \begin{tabular}{l|l|}
0 & $\mathrm{OK}$ \\
\end{tabular} & 0,067661 \\
\hline 281 & 1,24 & 0,60 & 1,08 & 0,95 & 0,61 & 0,96 & $-0,16$ & 7,71 & 1,79 & 1,08 & 0 & \begin{tabular}{l|l|}
0 & $\mathrm{OK}$ \\
\end{tabular} & 0,026644 \\
\hline 282 & 1,16 & 1,02 & 1,07 & 1,01 & 1,21 & 1,21 & $-0,13$ & 5,71 & 1,38 & 1,17 & 0 & \begin{tabular}{l|l}
0 & $\mathrm{OK}$ \\
\end{tabular} & 0,25567 \\
\hline 283 & 1,11 & 0,62 & 2,88 & 0,89 & 1,27 & 1,13 & $-0,49$ & 1,40 & 0,85 & 1,52 & 0 & \begin{tabular}{l|l}
0 & $\mathrm{OK}$ \\
\end{tabular} & 0 \\
\hline 284 & 1,53 & 0,86 & 2,05 & 0,08 & 0,91 & 1,11 & $-0,01$ & 0,67 & 1,17 & 1,10 & 0 & \begin{tabular}{l|l|}
0 & $\mathrm{OK}$ \\
\end{tabular} & 0,001746 \\
\hline 285 & 1,36 & 0,83 & 1,04 & 1,01 & 0,86 & 0,49 & $-0,09$ & 0,87 & 1,21 & 1,08 & 0 & \begin{tabular}{l|l|}
0 & $\mathrm{OK}$ \\
\end{tabular} & 0,076545 \\
\hline 286 & 0,75 & 0,44 & 1,68 & 0,91 & 0,47 & 1,46 & $-0,31$ & 1,14 & 0,49 & 3,26 & 0 & \begin{tabular}{l|l|}
0 & $\mathrm{OK}$ \\
\end{tabular} & 0 \\
\hline 287 & 1,07 & 0,76 & 2,36 & 0,85 & 1,07 & 1,02 & $-0,16$ & 0,72 & 2,23 & 1,06 & 0 & \begin{tabular}{l|l|}
0 & $\mathrm{OK}$ \\
\end{tabular} & 0,032621 \\
\hline 288 & 0,79 & 0,97 & 0,96 & 1,11 & 1,13 & 0,77 & $-0,06$ & 1,65 & 1,05 & 1,71 & 0 & \begin{tabular}{l|l|}
0 & $\mathrm{OK}$ \\
\end{tabular} & 0,123511 \\
\hline 289 & 0,75 & 0,43 & 3,97 & 0,89 & 0,98 & 1,26 & $-0,17$ & 2,10 & 2,22 & 1,35 & 0 & $0.0 K$ & 0,089176 \\
\hline
\end{tabular}

